\title{
Dating of the Lower Pleistocene Vertebrate Site of Tsiotra Vryssi (Mygdonia Basin, Greece): Biochronology, Magnetostratigraphy, and Cosmogenic Radionuclides
}

\author{
George E. Konidaris ${ }^{1, *(\mathbb{D}}$, Dimitris S. Kostopoulos ${ }^{2}\left(\right.$, Matteo Maron ${ }^{3} \mathbb{D}$, Mirjam Schaller ${ }^{4}\left(\mathbb{D}\right.$, Todd A. Ehlers ${ }^{4}$, \\ Elina Aidona ${ }^{5}$, Mattia Marini ${ }^{3}{ }^{(D}$, Vangelis Tourloukis ${ }^{1}{ }^{\infty}$, Giovanni Muttoni ${ }^{3}$, George D. Koufos ${ }^{2}$ \\ and Katerina Harvati ${ }^{1}$
}

check for

updates

Citation: Konidaris, G.E.;

Kostopoulos, D.S.; Maron, M.;

Schaller, M.; Ehlers, T.A.; Aidona, E.;

Marini, M.; Tourloukis, V.; Muttoni,

G.; Koufos, G.D.; et al. Dating of the Lower Pleistocene Vertebrate Site of Tsiotra Vryssi (Mygdonia Basin,

Greece): Biochronology,

Magnetostratigraphy, and

Cosmogenic Radionuclides.

Quaternary 2021, 4, 1. https://

doi.org/10.3390/quat4010001

Academic Editor: Maria Rita Palombo

Received: 11 November 2020

Accepted: 5 January 2021

Published: 8 January 2021

Corrected: 8 April 2022

Publisher's Note: MDPI stays neutral with regard to jurisdictional clai$\mathrm{ms}$ in published maps and institutional affiliations.

\section{Copyright: $\odot 2021$ by the authors. Li-} censee MDPI, Basel, Switzerland. This article is an open access article distributed under the terms and conditions of the Creative Commons Attribution (CC BY) license (https:// creativecommons.org/licenses/by/ $4.0 /)$.
1 Palaeoanthropology, Senckenberg Centre for Human Evolution and Palaeoenvironment, Eberhard Karls University of Tübingen, Rümelinstr. 23, 72070 Tübingen, Germany; vangelis.tourloukis@ifu.uni-tuebingen.de (V.T.); katerina.harvati@ifu.uni-tuebingen.de (K.H.)

2 Laboratory of Geology and Palaeontology, School of Geology, Aristotle University of Thessaloniki, 54124 Thessaloniki, Greece; dkostop@geo.auth.gr (D.S.K.); koufos@geo.auth.gr (G.D.K.)

3 Dipartimento di Scienze della Terra "Ardito Desio", University of Milan, via Mangiagalli 34, I-20133 Milan, Italy; matteo.maron@unimi.it (M.M.); mattia.marini@unimi.it (M.M.); giovanni.muttoni1@unimi.it (G.M.)

4 Department of Geosciences, Eberhard Karls University of Tübingen, Schnarrenbergstr. 94-96, 72076 Tübingen, Germany; mirjamschaller@uni-tuebingen.de (M.S.); todd.ehlers@uni-tuebingen.de (T.A.E.)

5 Department of Geophysics, School of Geology, Aristotle University of Thessaloniki,

54124 Thessaloniki, Greece; aidona@geo.auth.gr

* Correspondence: georgios.konidaris@uni.tuebingen.de

Abstract: Background and scope: The late Villafranchian large mammal age ( 2.0-1.2 Ma) of the Early Pleistocene is a crucial interval of time for mammal/hominin migrations and faunal turnovers in western Eurasia. However, an accurate chronological framework for the Balkans and adjacent territories is still missing, preventing pan-European biogeographic correlations and schemes. In this article, we report the first detailed chronological scheme for the late Villafranchian of southeastern Europe through a comprehensive and multidisciplinary dating approach (biochronology, magnetostratigraphy, and cosmogenic radionuclides) of the recently discovered Lower Pleistocene vertebrate site Tsiotra Vryssi (TSR) in the Mygdonia Basin, Greece. Results: The minimum burial ages $(1.88 \pm 0.16 \mathrm{Ma}, 2.10 \pm 0.18 \mathrm{Ma}$, and $1.98 \pm 0.18 \mathrm{Ma})$ provided by the method of cosmogenic radionuclides indicate that the normal magnetic polarity identified below the fossiliferous layer correlates to the Olduvai subchron (1.95-1.78 Ma; C2n). Therefore, an age younger than 1.78 Ma is indicated for the fossiliferous layer, which was deposited during reverse polarity chron C1r. These results are in agreement with the biochronological data, which further point to an upper age limit at $\sim 1.5 \mathrm{Ma}$. Overall, an age between 1.78 and $~ 1.5 \mathrm{Ma}$ (i.e., within the first part of the late Villafranchian) is proposed for the TSR fauna. Conclusions: Our results not only provide age constraints for the local mammal faunal succession, thus allowing for a better understanding of faunal changes within the same sedimentary basin, but also contribute to improving correlations on a broader scale, leading to more accurate biogeographic, palaeoecological, and taphonomic interpretations.

Keywords: Villafranchian; Pleistocene; Balkans; southeastern Europe; mammals; biochronology; palaeomagnetism; cosmogenic radionuclides

\section{Introduction}

The fascinating world of the Pleistocene has long attracted the interest of scientists from different disciplines. The rich mammal record, including iconic animals such as mammoths, saber-toothed cats, giant hyenas, and giant deer; the evolution and dispersals of our own genus Homo; and the large-scale global climatic fluctuations are only some 
of the highly intriguing research areas that characterize the Pleistocene. The late Villafranchian large mammal age, defined in Europe as starting at $2.0 \mathrm{Ma}$ [1-3] and ending at $\sim 1.2 \mathrm{Ma}$ [4-6] at the beginning of the subsequent Epivillafranchian, is a crucial period in the evolution of the Early Pleistocene terrestrial ecosystems of Eurasia. The climatic conditions during the late Villafranchian resulted in the (intermittent) expansion of open-forest and savanna-like landscapes from the Transcaucasian to the European peri-Mediterranean regions $[7,8]$. In turn, this affected the structure and dynamics of the western Eurasian mammal palaeocommunities tremendously, triggering faunal turnovers, extinctions, and dispersal events [2,7,9], including the first arrival of hominins at the gates of Europe [10,11] Indeed, the fossil record of the northern/eastern peri-Black Sea region and southern Europe documents the arrival during this period of new immigrants of Asian and African origin along with the regional extinction of several, previously well-adapted lineages $[1,2,7,12]$. The analysis and interpretation of these mammal bioevents and their underlying mechanisms necessitate the establishment of an accurate chronological framework. The discovery of several new fossiliferous localities and the re-assessment of older ones, in combination with improved dating methodologies, have substantially enhanced our knowledge about the Early Pleistocene of Europe. However, there are still several open issues that need to be addressed. For instance, the dating methods (either direct or indirect) that are commonly applied to Quaternary deposits and fossils, have their own assumptions, as well as assets and limitations (see [13] for an overview) that bring uncertainties in age estimations, thus, limiting high-resolution correlations across different sites. Moreover, although Early Pleistocene local European records and faunal successions have been relatively well explored and defined through time, pan-European biogeographic correlations and schemes (largescale biochronology) are still limited (see also [1]) and poorly supported by an accurate chronological framework, especially for the Balkans and adjacent territories. As a result, our understanding of the palaeoecological conditions, including corridors or barriers that may have enabled or impeded the dispersal of several large mammals in this timeframe, is highly obscured. Additionally, these continental-scale biogeographic extrapolations rely mostly on spot data from sedimentary basins from distant geographic regions, such as Italy, Spain, France, and the Balkans (Figure 1), which, as stated above, are difficult to correlate, resulting in the following uncertainties especially when attempting to resolve: (i) possible discontinuities in the fossil record, both local or composite (faunal units); (ii) the degree of diachrony or synchrony of the various dispersal events in response, for example, to Pleistocene climate variability; and (iii) the different geological, climatic, environmental, and taphonomic conditions at the various sites (see also [14,15]).

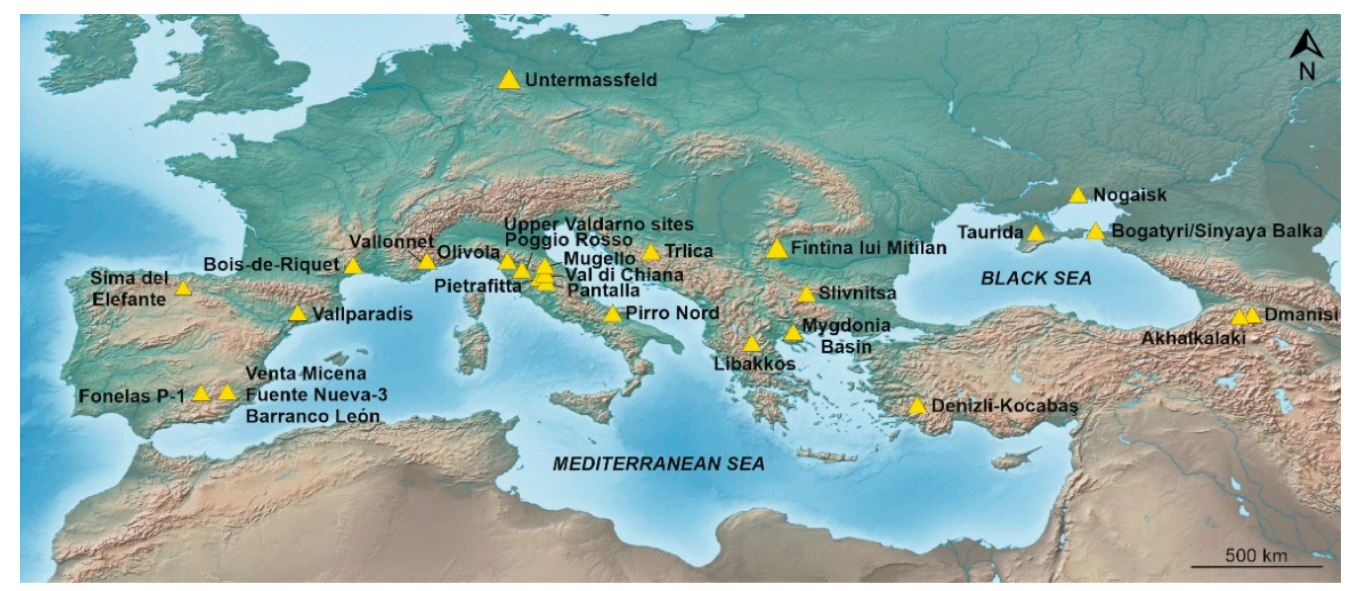

Figure 1. Selected sites of the Caucasus, the northern peri-Black Sea territory, and the northern peri-Mediterranean region, attributed to the late Villafranchian and Epivillafranchian, $\sim 2.0-0.8 \mathrm{Ma}$ (map from Natural Earth, naturalearthdata.com). 
The Lower Pleistocene fossiliferous localities of the Mygdonia Basin (central Macedonia, Greece) have been known since the end of the 1970s [16-18]. Numerous fieldwork campaigns, carried out for several decades, have led to the discovery of several sites, and to the excavation and study of a great number of fossils. This work has significantly enriched the Pleistocene fossil record of Greece [19-22]. Currently, there are twelve open-air Lower Pleistocene vertebrate sites known in the Mygdonia Basin (Figure 2), located in at least three distinct stratigraphic horizons and correlated to different parts of the late Villafranchian. Owing to their rich and diversified fauna of different evolutionary stages, the Mygdonia sites (1) permit identification and tracking of faunal and evolutionary changes within the stratigraphic succession of the same sedimentary basin, and thus enhance our knowledge on the evolution and taxonomy of several vertebrate taxa and mammal turnovers; (2) allow a more precise biostratigraphic correlation with other fossil assemblages of Greece and southeastern Europe; and (3) contribute to palaeogeographical interpretations and the better understanding of the palaeoenvironmental conditions, offering overall valuable insights into the Early Pleistocene terrestrial ecosystems of Europe. Moreover, Greece and the Balkans in general, located in the southeastern corner of Europe, occupy a critical position for the dispersals of mammals and hominins to and from Europe, western Asia, and the Levant/Africa [22-27], highlighting the need for systematic and deeper investigations in key locations, such as the Mygdonia Basin. Importantly for the Pleistocene continental biostratigraphy of Greece, the late Villafranchian localities of the Mygdonia Basin, together with the older ones from the Aliakmon Basin (e.g., Dafnero) and the younger ones from the Megalopolis Basin (e.g., Marathousa-1 and Kyparissia sites), all of which are characterized by long stratigraphic sequences, altogether cover a rather continuous faunal sequence spanning from the middle Villafranchian to the Galerian [22,28-31], and permit the detailed study of the Early-Middle Pleistocene fossil and palaeoenvironmental record of Greece.
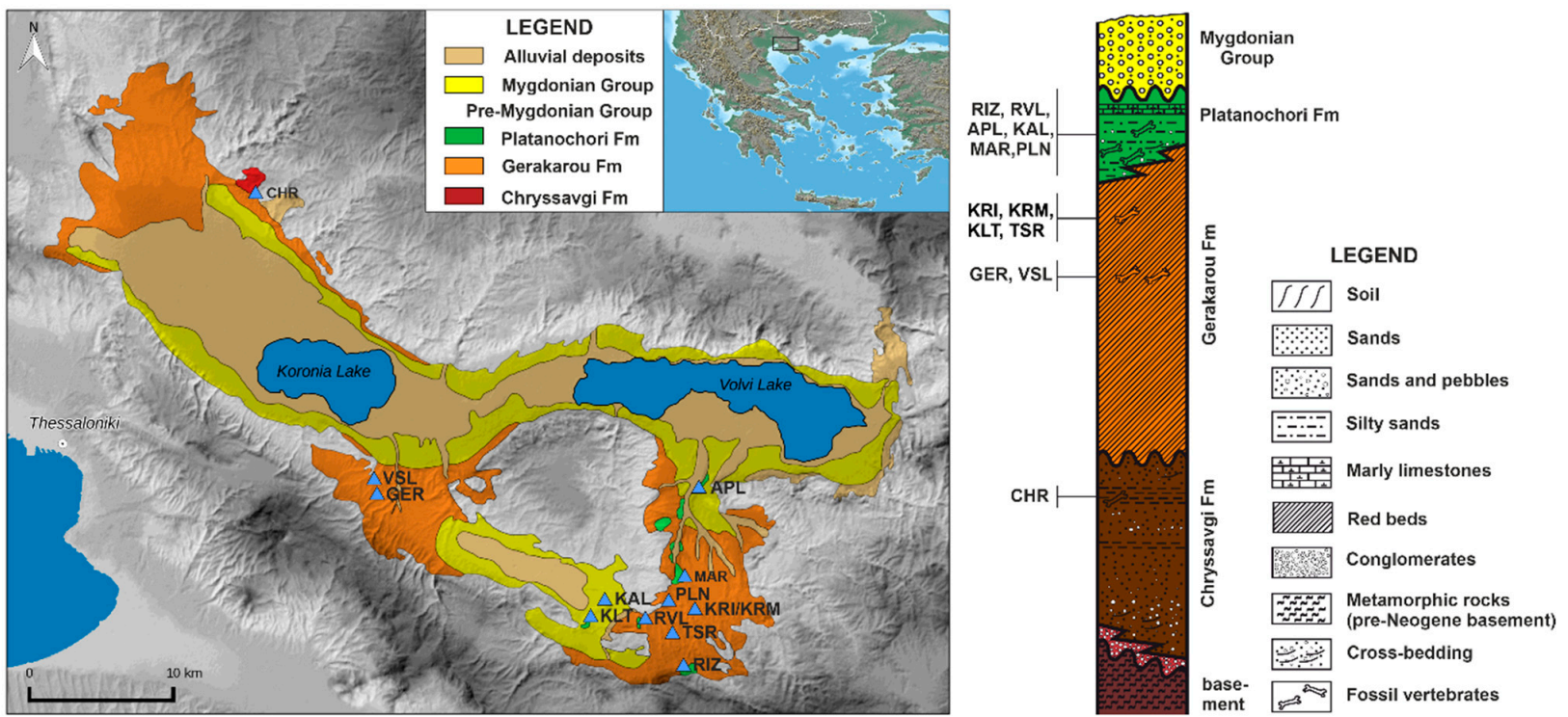

Figure 2. Geological map of the Neogene and Quaternary lithostratigraphic units of the Mygdonia Basin (left) and simplified composite stratigraphic column of the basin indicating the position of the fossiliferous localities (right). Modified from [21] and data from [19]. Map of Greece from Copernicus Land Monitoring Service (https://land.copernicus.eu/).

In this article, we report the first detailed chronological scheme for the late Villafranchian from southeastern Europe. This has been achieved through a comprehensive and multidisciplinary dating approach (biochronology, magnetostratigraphy, and cosmogenic radionuclides) of the recently discovered Lower Pleistocene vertebrate site Tsiotra Vryssi (TSR) in the Mygdonia Basin. More specifically, the aims of the present study are the following: (1) to precisely constrain the age of the site by means of a combination of dating methods; (2) to follow more thoroughly the regional mammal succession through 
time and to enhance our knowledge about the relationships among the various Mygdonia Basin localities; and (3) to correlate TSR with other Lower Pleistocene localities of western Eurasia, thus, placing TSR within the larger discussions on Early Pleistocene mammal diversity and bioevents. As one of the first such studies from the Early Pleistocene of Greece and Southeastern Europe in general, and the first from the Mygdonia Basin, this study aspires to render TSR and the surrounding fossil sites to be a western Eurasian reference region for the chronological correlation of other localities and for the study and comparison of their vertebrate assemblages.

\section{Geological Setting and Fossiliferous Locality}

The Mygdonia Basin is located in central Macedonia (Greece), to the northeast of Thessaloniki, and represents an elongated east-west trending tectonic depression, the formation of which started during the early-middle Miocene with the incipient development of the Pre-Mygdonia Basin (Figure 2). During the Neogene-Early Pleistocene, the basin was filled with fluvial/fluvio-torrential and lacustrine sediments, while at the beginning of the Middle Pleistocene a new tectonic event led to further subdivisions into smaller basins, which were subsequently filled mostly by lacustrine sediments [32]. These Neogene to Quaternary deposits were subdivided into two high-rank lithostratigraphic units, namely the Pre-Mygdonian Group (Neogene to Early Pleistocene) and the Mygdonian Group (Middle Pleistocene to Holocene). The Pre-Mygdonian Group can be further subdivided into three successive lithostratigraphic formations (Fm), the Chryssavgi Fm, the Gerakarou Fm and, the Platanochori Fm [19]. The following six Lower Pleistocene fossiliferous sites have been discovered, to date, in the upper part of the Gerakarou Fm: Gerakarou-1 (GER), Vassiloudi (VSL), Krimni-1 and -2 (KRI and KRM), Kalamoto-2 (KLT), and Tsiotra Vryssi (TSR). The study of their assemblages indicated that, although the localities are not isochronous, all of them can be correlated to the first part of the late Villafranchian (Early Pleistocene) [19-21]. The overlying Platanochori Fm includes six more fossiliferous sites, i.e., Apollonia-1 (APL), Ravin of Voulgarakis (RVL), Riza-1 (RIZ), Marathoussa (MAR), Kalamoto-1 (KAL), and Platanochori-1 (PLN) (Figure 2), which are correlated to the second part of the late Villafranchian [19-21]. More information on the stratigraphy and the fossiliferous sites can be found in [19] and [21].

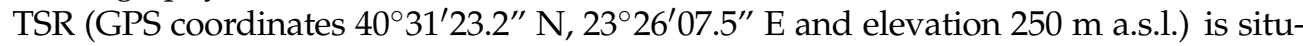
ated in the Gerakarou Fm, the most widely exposed sedimentary unit across the Mygdonia Basin (Figure 2) with a thickness in excess of $100 \mathrm{~m}$. The Gerakarou Fm consists of redbrown sands, gravels, sandy silts, and clays, deposited in a fluvial/fluvio-torrential environment [19]. TSR was discovered in 2014 during a targeted survey by a joint team from the Aristotle University of Thessaloniki and the Paleoanthropology working group at the Eberhard Karls University of Tübingen [21]. It has since yielded a wealth of large mammal fossils (Figure 3), as well as some micromammals, reptiles, and birds. The $\sim 1 \mathrm{~m}$ thick fossiliferous unit Geo 2a (Figure 4) consists of pale brown-dark yellowish brown poorly sorted silts, locally intercalated by cm-thick lenses of medium-coarse grained sands and is relatively more clayey in its uppermost part. The spatial taphonomic analysis of the faunal remains and the sedimentological and micromorphological studies indicated multiple dispersion events and recurrent spatial rearrangement of a lag, (peri)autochthonous assemblage, consistent with the cyclical lateral switching of a braided fluvial system [33]. The large mammal assemblage is rich and diversified and, so far, comprises 14 species ([21,34-36] and unpublished data; a cranium belonging to the felid Megantereon was discovered in the excavation season of 2018, whose complete study is pending, however, the genus is included in the herein updated faunal list). The fauna is dominated by horses (Equus), but also includes several other herbivore taxa, such as bovids (Leptobos, Bison, Pontoceros), deer (Cervus, Praemegaceros), rhinos (Stephanorhinus), mammoths (Mammuthus), and giraffids (Palaeotragus). Carnivores are well represented and include wolf-like dogs (Canis), giant hyenas (Pachycrocuta), bears (Ursus), and saber-toothed cats (Megantereon) (Table 1). TSR has yielded more than 2000 mammalian bones and teeth to date, which are stored at the Museum of Geology, Palaeontology, and Palaeoanthropology of the 
Laboratory of Geology and Palaeontology at the Aristotle University of Thessaloniki, Greece (LGPUT).
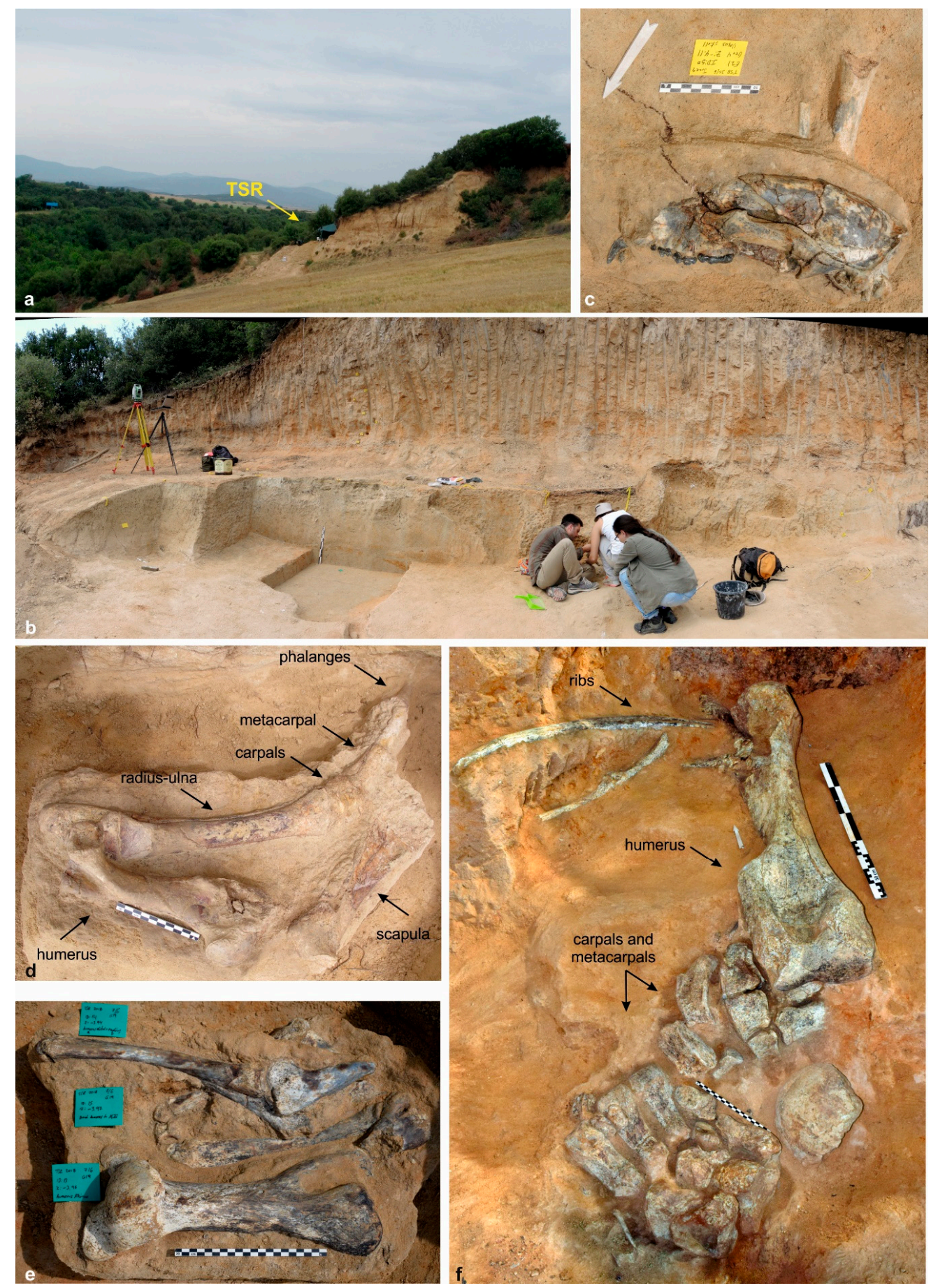

Figure 3. Tsiotra Vryssi site and excavation photos. (a) General view of the site; (b)
Closer view of the site; (c) Cranium of a bear (Ursus etruscus); (d) Complete front limb of a horse (Equus sp.); (e) Accumulation of isolated and articulated bones of a large bovid, a horse, and a rhino (Stephanorhinus sp.); (f) Skeletal remains of a mammoth (Mammuthus meridionalis). 


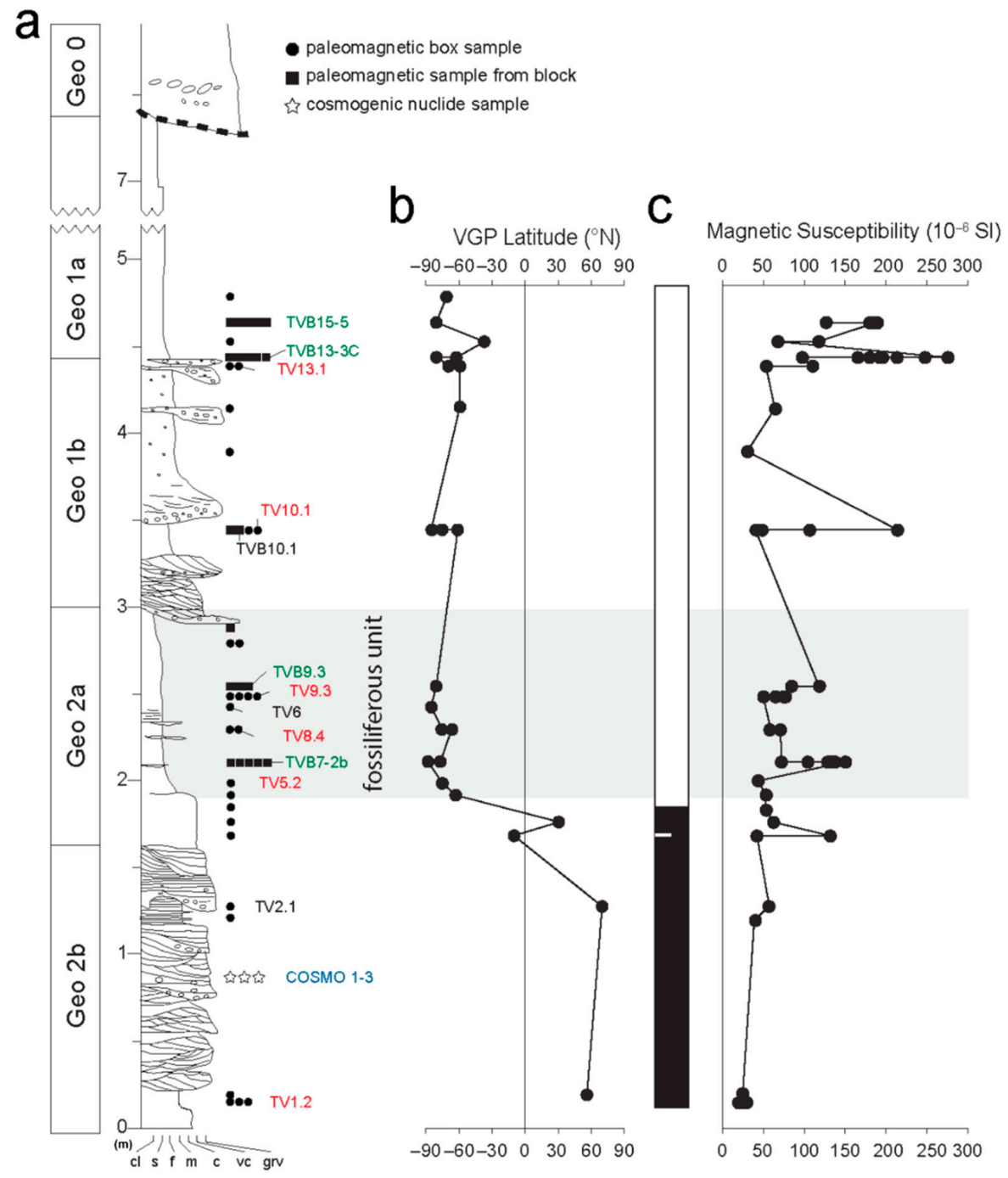

Figure 4. (a) Stratigraphic log (modified from [33]) of the Tsiotra Vryssi section with location of the samples for magnetostratigraphy and experiments for rock magnetism, and for cosmogenic radionuclides dating; (b) Latitude of the virtual geomagnetic poles (VGP) with interpreted magnetostratigraphy (black is normal polarity, white reverse polarity); (c) Magnetic susceptibility K.

Table 1. Preliminary faunal list of the large mammals from Tsiotra Vryssi (excavation seasons 2014-2019). Faunal list updated from [21], based on [34-36] and unpublished data.

\begin{tabular}{|c|c|c|c|}
\hline Order & Family & Genus & Species \\
\hline Proboscidea & Elephantidae & Mammuthus & meridionalis \\
\hline \multirow{4}{*}{ Carnivora } & Canidae & Canis & sp. \\
\hline & Ursidae & Ursus & etruscus \\
\hline & Hyaenidae & Pachycrocuta & brevirostris \\
\hline & Felidae & Megantereon & sp. \\
\hline \multirow{3}{*}{ Perissodactyla } & Equidae & Equus & sp. (medium-sized) \\
\hline & & Equus & sp. (large-sized) \\
\hline & Rhinocerotidae & Stephanorhinus & sp. \\
\hline \multirow{6}{*}{ Artiodactyla } & Giraffidae & Palaeotragus & sp. \\
\hline & Cervidae & Cervus & sp. \\
\hline & & Praemegaceros & sp. \\
\hline & Bovidae & Pontoceros & sp. \\
\hline & & Leptobos & sp. \\
\hline & & Bison & cf. degiulli \\
\hline
\end{tabular}




\section{Methodology}

Cosmogenic radionuclides: Pairs of in situ-produced cosmogenic radionuclides analyzed in fluvial sediment can be used for burial dating based on different decay rates of the two isotopes (e.g., [37,38]). Age determination of sediment deposition in the study area makes use of simple burial dating with in situ-produced ${ }^{26} \mathrm{Al}$ and ${ }^{10} \mathrm{Be}$ concentrations in quartz (e.g., [39]). Three sand samples from the same stratigraphic depth located at $\sim 1 \mathrm{~m}$ below the bottom of the Geo $2 \mathrm{~b}$ fossiliferous layer (Figure $4 \mathrm{a}$ ) were sieved to 0.25 to $0.50 \mathrm{~mm}$. Quartz was separated and cleaned to reach $\mathrm{Al}$ concentrations of $\sim 100 \mathrm{ppm}$. Al and Be were extracted according to protocols outlined in $[40]$. The ${ }^{26} \mathrm{Al} /{ }^{27} \mathrm{Al}$ and ${ }^{10} \mathrm{Be} /{ }^{9} \mathrm{Be}$ ratios of samples, blanks, and standards were measured at the AMS facility of Cologne (Germany). The ${ }^{26} \mathrm{Al}$ and ${ }^{10} \mathrm{Be}$ concentrations of samples were corrected for chemistry blanks of $1.93 \times 10^{5}$ and $4.97 \times 10^{4}$ atoms, respectively. Standards used for calibration of the ${ }^{26} \mathrm{Al} /{ }^{27} \mathrm{Al}$ and ${ }^{10} \mathrm{Be} /{ }^{9} \mathrm{Be}$ ratios were KN01-5-3 and KN01-4-3 [41], as well as KN01-6-2 and KN01-5-3 [42], respectively. All sample preparation was conducted at the University of Tübingen.

Simple burial dating was performed with a MatLab script modified from [40] based on [39]. Decay constants used for ${ }^{26} \mathrm{Al}$ and ${ }^{10}$ Be were $(9.830 \pm 0.250) \times 10^{-7}$ [43] and $(4.997 \pm 0.043) \times 10^{-7}[44,45]$. The sea level and high latitude (SLHL) production rates for ${ }^{26} \mathrm{Al}$ were $28.54,0.84$, and 0.081 atoms $/\left(\mathrm{g}_{(\mathrm{qtz})} \mathrm{yr}\right)$ for nucleonic, stopped muonic, and fast muonic production, respectively [46,47]. The SLHL production rates used were 3.92, 0.012, and 0.039 atoms $/\left(\mathrm{g}_{(\mathrm{qtz})} \mathrm{yr}\right)$ for nucleonic, stopped muonic, and fast muonic ${ }^{10}$ Be production, respectively $[46,47]$. The ${ }^{26} \mathrm{Al} /{ }^{10} \mathrm{Be}$ ratio of production at SLHL was $\sim 7.4$. The SLHL production rates were scaled to the sample location with the online calculator of Marrero et al. [48] using the scaling procedure "SA" based on Lifton et al. [49]. Production rates at individual sampling depths were calculated based on nucleonic, stopped muonic, and fast muonic adsorption lengths, which were 157,1500 , and $4320 \mathrm{~g} / \mathrm{cm}^{2}$, respectively [46]. Overburden was assumed to be at least $3000 \mathrm{~cm}$ with a constant density over time of $2.0 \pm 0.1 \mathrm{~g} / \mathrm{cm}^{3}$. This overburden results in a calculated simple burial age, which can be considered to be a minimum burial age [39]. The production rate at the sample location was used as the production rate of the sediment source area, because the production rate of the palaeo-sediment source area was unknown. Therefore, this production rate is considered to be a minimum production rate for a source area located at higher elevation, and hence results in a maximum calculated burial age. Thus, based on the above, the calculated simple burial age has the potential to be either younger or older than the actual age, and we interpreted it to be the best estimate of the actual burial age given with available constraints.

Palaeomagnetism: A total of 52 standard $(10 \mathrm{cc})$ samples were recovered from 4.5 stratigraphic meters of the Tsiotra Vryssi section (Figure 4a), either by manually inserting plastic boxes in the outcrop section (32 specimens) or by hand-sampling six oriented blocks, each yielding up to 5 specimens, which were subsequently consolidated and cored in the laboratory. All analyses were conducted at the Alpine Laboratory of Paleomagnetism (ALP) of Peveragno (Italy), with the exception of the thermal demagnetization experiments, which were performed at the Department of Geophysics of the Aristotle University of Thessaloniki.

The low-field magnetic susceptibility ( $k$ ) was measured with an AGICO KLY-3 Kappabridge. Then, samples were AF (Alternating Field) demagnetized in steps of 5-10 mT up to $100 \mathrm{mT}$ with a $2 \mathrm{G}$ Enterprises AF Degausser. The natural remanent magnetization (NRM) was measured after each demagnetization step with a 2G Enterprises 755 DCSQUID cryogenic magnetometer located in a magnetically shielded room. The directions of the NRM were plotted on standard vector end-point demagnetization diagrams and the characteristic remanent magnetization (ChRM), where present, was isolated with standard principal component analysis on selected data. Isothermal remanent magnetization (IRM) acquisition experiments were performed on 6 representative samples using an ASC Scientific IM-10-30 impulse magnetizer and an AGICO JR-6 spinner magnetometer. Finally, thermal demagnetization experiments of a three-component IRM adopting $2 \mathrm{~T}, 0.5 \mathrm{~T}$, and 
$0.1 \mathrm{~T}$ orthogonal fields were performed on another set of 4 samples with a Minispin spinner magnetometer (Molspin) at the Department of Geophysics of the Aristotle University of Thessaloniki.

Faunal similarity analysis: In order to examine the similarities and relationships of TSR with other Early Pleistocene localities, we performed hierarchical cluster analysis at the genus level. Twenty-four faunas/sites were selected ranging geographically from Georgia to Spain and spanning chronologically from $\sim 2.5$ to $\sim 0.8 \mathrm{Ma}$ (middle Villafranchian to Epivillafranchian). A total of 56 genera of large mammals (excluding primates) were considered. The analysis was conducted with the PAST software, version 4.04 [50]. The Q-mode dendrogram (with unweighted pair-group average (UPGMA) algorithm) was acquired by applying the similarity index Raup-Crick, which is used to statistically test presence and absence data through a randomization method [51]. The faunal assemblages considered are Fonelas P-1 [52], Untermassfeld [53,54], Gerakarou-1, Krimni-1, Apollonia1, Libakos [55], Slivnitsa [56], Poggio Rosso [57], Kalamoto-2 [20], Dmanisi [11], Pirro 10 [58], Sima del Elefante (TE-) Lower Red Unit (LRU) TE8-14 [59], Vallparadís Estació Middle Unit, Layers EVT6-VT8 [60,61], Venta Micena [62], Val di Chiana [9], Pietrafitta [9], Trlica 11-10 [63], Vallonnet [64], Fuente Nueva 3 [62], Barranco León [62], Pantalla [65], Dafnero [66] and Taurida [67], with faunal updates and taxonomical reviews by us for the Greek sites.

\section{Results}

\subsection{Cosmogenic Radionuclides}

In situ produced cosmogenic radionuclide concentrations of ${ }^{26} \mathrm{Al}$ and ${ }^{10} \mathrm{Be}$ from three samples (Figure $4 \mathrm{a})$ range from $(31.88 \pm 1.74)$ to $(37.07 \pm 1.91) \times 10^{4}$ atoms $/ \mathrm{g}_{(\mathrm{qtz})}$ and $(9.40 \pm 0.33)$ to $(10.51 \pm 0.42) \times 10^{4}$ atoms $/ \mathrm{g}_{\text {(qtz) }}$. The ${ }^{26} \mathrm{Al} /{ }^{10} \mathrm{Be}$ ratios are $3.53 \pm 0.23$, $3.18 \pm 0.20$, and $3.39 \pm 0.22$ for the three samples from the same stratigraphic layer. These ratios result in simple burial ages of $1.88 \pm 0.16 \mathrm{Ma}, 2.10 \pm 0.18 \mathrm{Ma}$, and $1.98 \pm 0.18 \mathrm{Ma}$, respectively (Table 2).

Table 2. Cosmogenic radionuclide information for samples from the stratigraphic layer Geo 2b of Tsiotra Vryssi.

\begin{tabular}{|c|c|c|c|c|c|c|c|c|c|c|c|c|c|}
\hline $\begin{array}{c}\text { Sample } \\
\text { ID }\end{array}$ & Lab ID & $\begin{array}{l}\text { Grain Size } \\
\quad(\mu \mathrm{m})\end{array}$ & $\begin{array}{c}\text { Qtz } \\
\text { Dissolved } \\
\text { (g) }\end{array}$ & $\begin{array}{c}\mathrm{m}\left({ }^{27} \mathrm{Al}\right) \\
(\mathrm{ppm})\end{array}$ & ${ }^{26} \mathrm{Al} /{ }^{27} \mathrm{Al}$ & $\begin{array}{c}1 \sigma \text { Error } \\
(\%)\end{array}$ & $\begin{array}{l}{ }^{26} \mathrm{Al} \text { Conc. } \\
\qquad 10^{4} \\
\text { atoms/g( }(\mathrm{qtz})\end{array}$ & $\begin{array}{c}\mathrm{m}\left({ }^{9} \mathrm{Be}\right) \\
(\mathrm{mg})\end{array}$ & ${ }^{10} \mathrm{Be} /{ }^{9} \mathrm{Be}$ & $\begin{array}{c}1 \sigma \text { Error } \\
(\%)\end{array}$ & $\begin{array}{l}{ }^{10} \text { Be Conc. } \\
\qquad 10^{4} \\
\text { atoms/g(qtz) }\end{array}$ & ${ }^{26} \mathrm{Al} /{ }^{10} \mathrm{Be}$ & $\begin{array}{c}\text { Simple } \\
\text { Burial Age } \\
\text { (Myr) }\end{array}$ \\
\hline COSMO 1 & GL11 & & 46.76 & 121 & $1.39 \times 10^{-13}$ & & $37.07 \pm 1.91$ & & $2.16 \times 10^{-13}$ & & $10.51 \pm 0.42$ & & 1.54 \\
\hline COSMO 2 & GL7 & & 76.52 & 81 & $1.80 \times 10^{-13}$ & 5.23 & $32.48 \pm 1.70$ & 0.2868 & $4.10 \times$ & 3.34 & $10.23 \pm$ & 3.18 & $1.75 \pm 0.10$ \\
\hline COSMO 3 & GL8 & $250-500$ & 55.97 & 65 & $2.20 \times 10^{-13}$ & 5.44 & $31.88 \pm 1.74$ & 0.2874 & $2.76 \times 10^{-13}$ & 3.51 & $9.40 \pm 0.33$ & $3.39 \pm 0.22$ & $1.62 \pm 0.10$ \\
\hline
\end{tabular}

\subsection{Magnetic Properties}

Values of $k$ are relatively low all along the section (Figure $4 c$ ), with an average value of $105 \times 10^{-6}$ SI. Samples from the basal part of the sequence, between 0 and $2 \mathrm{~m}$ from the base, show the lowest values $\left(15-60 \times 10^{-6} \mathrm{SI}\right)$, whereas peak $\mathrm{k}$ values were measured from samples collected at $2 \mathrm{~m}$ (ca. $\left.150 \times 10^{-6} \mathrm{SI}\right), 3.5 \mathrm{~m}$ (ca. $215 \times 10^{-6} \mathrm{SI}$ ), and $4.5 \mathrm{~m}$ (ca. $275 \times 10^{-6} \mathrm{SI}$ ). The IRM acquisition curves indicate the dominance of low to medium coercivity phases ( 80 to $400 \mathrm{mT}$ ) with saturation reached at $2500 \mathrm{mT}$, suggesting the presence of a mixture of magnetite/maghemite and hematite (Figure 5A). The three-axis IRM experiments [68] show that the medium (0.5 T) and high-coercivity (2 T) curves have maximum unblocking temperatures of $650-675^{\circ} \mathrm{C}$ (Figure $5 \mathrm{~B}$ ), consistent with the presence of hematite. The low-coercivity $(0.1 \mathrm{~T})$ curve declines at a rather constant pace from room temperature up to $350-400{ }^{\circ} \mathrm{C}$, before recording a rapid decrease at $\sim 600{ }^{\circ} \mathrm{C}$, followed by a slower decrease up to $650-675^{\circ} \mathrm{C}$ (Figure 5B); this behavior could be interpreted to reflect progressive oxidation of an original maghemite/magnetite phase into a secondary hematite. 


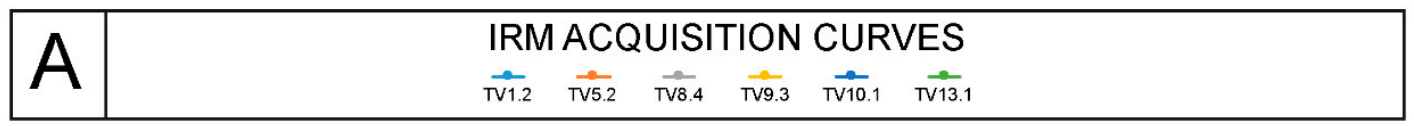
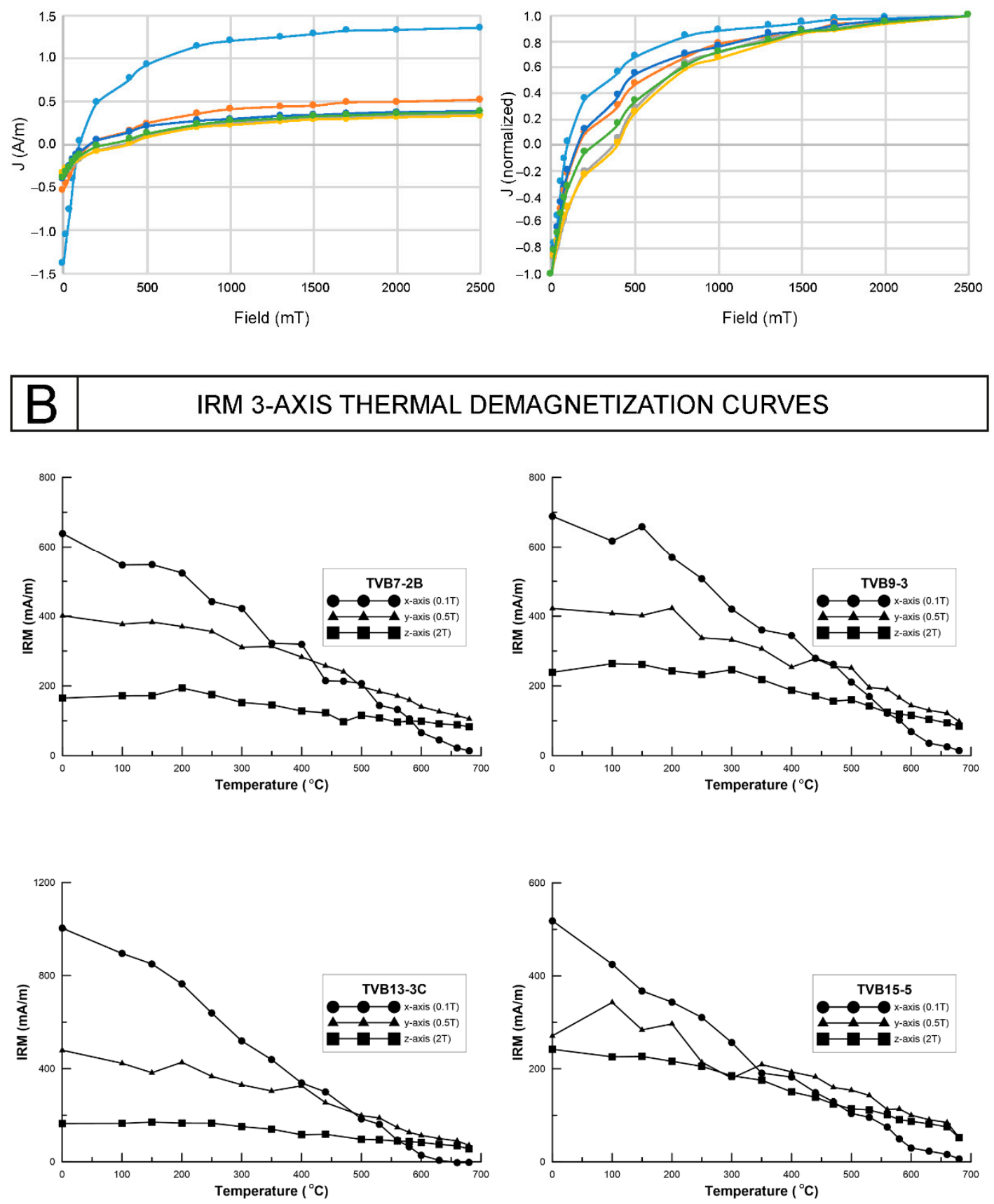

Figure 5. (A) Isothermal remanent magnetization (IRM) backfield acquisition curves and (B) thermal decay curves of three-axis IRM of selected samples from Tsiotra Vryssi (see Figure 4 for location).

\subsection{Magnetostratigraphy}

Bipolar ChRM component directions, oriented north-and-down or south-and-up in in situ coordinates and within a field range of $\sim 10-70 \mathrm{mT}$, were isolated in 23 of 38 demagnetized samples from the Tsiotra Vryssi section (Figure 6). The mean ChRM direction, calculated by applying standard Fisher statistics on $n=23$ ChRM directions (declination $=176.8^{\circ} \mathrm{E}$, inclination $=-40.5^{\circ}, \alpha_{95}=10.7^{\circ}$, Table 3 and Figure 7 ), led to a palaeomagnetic pole position of latitude $72.4^{\circ} \mathrm{N}$ and longitude $213.2^{\circ} \mathrm{E}\left(\mathrm{A}_{95}=7.8^{\circ}\right)$. The McFadden and McElhinny [69] reversal test applied to the ChRM component directions in in situ 
coordinates result was indeterminate $(\mathrm{k} 1 \neq \mathrm{k} 2$, type $\mathrm{I})$, probably due to the small number of components used.
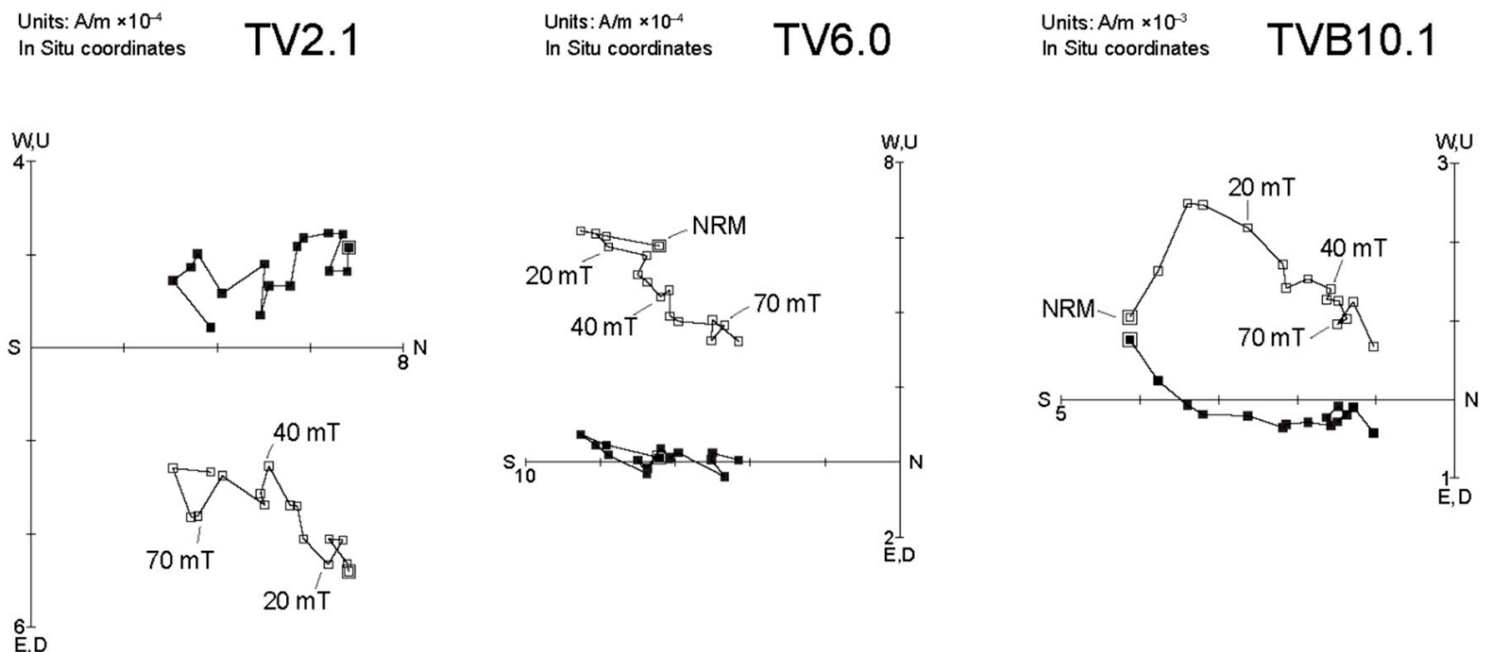

Figure 6. Vector end-point demagnetization diagrams of key samples from the Tsiotra Vryssi section in in situ coordinates. Closed squares are projections onto the horizontal plane, and open squares are projections onto the vertical plane. Applied AF covers a range $0-100 \mathrm{mT}$ with steps of $5 \mathrm{mT}$ up to $50 \mathrm{mT}$ and of $10 \mathrm{mT}$ up to $100 \mathrm{mT}$.

Table 3. Palaeomagnetic mean direction and pole form the Tsiotra Vryssi characteristic remanent magnetization (ChRM) component directions. N, number of samples; k, Fisher precision parameter; $\alpha_{95}$, radius of the cone of $95 \%$ confidence; Dec., mean declination of the ChRM component; Inc., mean inclination of the ChRM component; Lat., latitude of palaeomagnetic pole; Long., longitude of palaeomagnetic pole; $A_{95}$, radius of the cone of $95 \%$ confidence around the palaeomagnetic pole.

\begin{tabular}{cccccccc}
\hline & \multicolumn{3}{c}{$\begin{array}{c}\text { Mean Directions } \\
\text { In Situ }\end{array}$} & & \multicolumn{3}{c}{ Palaeopole } \\
\hline $\mathbf{N}$ & $\mathbf{k}$ & $\boldsymbol{\alpha}_{\mathbf{9 5}}$ & Dec. & Inc. & Lat. & Long. & $\mathrm{A}_{95}$ \\
\hline 23 & 9.0 & $10.7^{\circ}$ & $176.8^{\circ} \mathrm{E}$ & $-40.5^{\circ}$ & $72.4^{\circ} \mathrm{N}$ & $213.2^{\circ} \mathrm{E}$ & $7.8^{\circ}$ \\
\hline
\end{tabular}

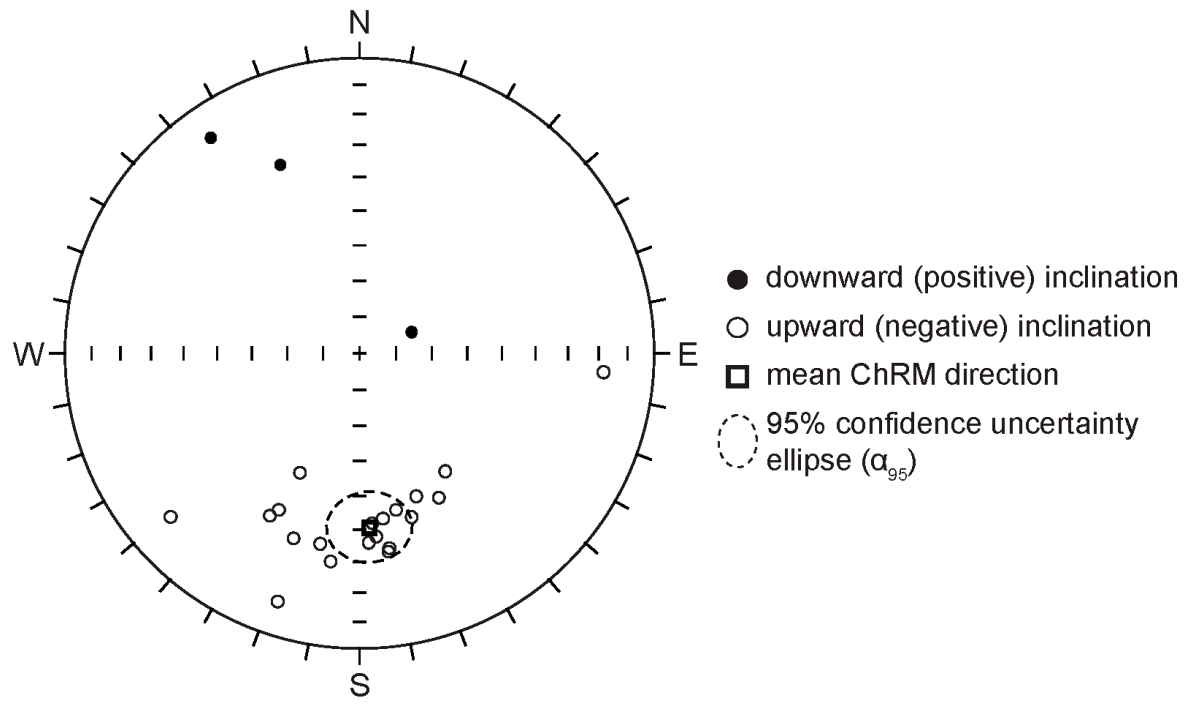

Figure 7. Equal-area projections of the ChRM component directions from the Tsiotra Vryssi section (see Table 3 for mean direction). 
When plotted versus stratigraphic depth, the latitude (positive for normal polarity, negative for reverse polarity) of virtual geomagnetic poles (VGPs) calculated for each ChRM component direction (Figure 4) define a lower incomplete normal magnetic polarity interval overlain by an incomplete reverse polarity interval (Figure 4).

\subsection{Biochronology}

The presence of the large-sized hyena Pachycrocuta brevirostris in the TSR fauna indicates a post-middle Villafranchian age, as the migration of this species to Europe, referred to as the "Pachycrocuta brevirostris event", is tentatively dated at $2.0 \mathrm{Ma}$ [3] and marks the beginning of the late Villafranchian [2]. Approximately at the same time, Canis sensu stricto also becomes widespread [70,71]. This taxon's earliest occurrences in the Balkan Peninsula are traced at Slivnitsa (Bulgaria) and Gerakarou 1, correlated to the middle/late Villafranchian boundary [24,72,73]. The bear Ursus etruscus from TSR differs from the middle Villafranchian specimens of Saint-Vallier (France) and is more similar to the typical U. etruscus from Upper Valdarno (Olivola and Tasso Faunal Units (FUs) of Italy); however, it is most similar to the specimens from Pietrafitta (Farneta FU) [36], tentatively dated at ca. 1.7-1.5 Ma [1,3,74]. The large-sized deer Praemegaceros and the spiral-horned antelope Pontoceros first occur at Dmanisi and are present soon after in the northern peri-Black Sea region and the Balkan Peninsula [75,76], while Praemegaceros appears in Italy during the Farneta FU [1] and in Spain after $\sim 1.6 \mathrm{Ma}$, at the Orce sites [77]. The giraffid Palaeotragus is well recorded during the middle Villafranchian, and is also present in the late Villafranchian of Fonelas P-1, Dmanisi, Libakos, and Denizli-Kocabaş [78], but has not been documented, as yet, in the fossil-rich Pirro Nord, the Orce sites, Apollonia 1, or Untermassfeld, collectively correlated to the second half of the late Villafranchian and Epivillafranchian [1,7]. The strongest biochronological indicator recovered so far from TSR is the co-existence of the large-sized bovids Leptobos and Bison. Leptobos was present in Europe during the early and middle Villafranchian but also survived during the first part of the late Villafranchian (e.g., [65,79]). The earliest record of bisons in western Eurasia is documented at Dmanisi ( 1.8 Ma), while they subsequently dispersed into peri-Mediterranean Europe from 1.7-1.5 Ma onwards (e.g., Farneta FU, Orce sites, Pirro Nord, Apollonia-1, Sima del Elefante-TE9). The Leptobos-Bison co-existence is relatively rare; apart from TSR, it is recorded in Mygdonia Basin at Krimni-1 and Kalamoto-2, as well as further afield at Trlica 11-10 in Montenegro, the Taurida Cave in Russia and Pietrafitta in Italy $[35,67,75,79,80]$.

In order to examine more comprehensively the overall faunal relationships and similarities between TSR and other middle Villafranchian-Epivillafranchian localities of western Eurasia, we conducted hierarchical cluster analysis at the genus level. The resulting Q-mode dendrogram (Figure 8) clusters the faunas chronologically (rather than geographically). Two main clusters emerge, reflecting the significant faunal reorganization (even at genus level) close to $\sim 2.0 \mathrm{Ma}$ at the middle/late Villafranchian boundary, i.e., cluster A, including the middle and middle/late Villafranchian faunas (Dafnero and Slivnitsa) and cluster B encompassing the late Villafranchian to Epivillafranchian ones. Cluster B is further divided into two subclusters, i.e., B1 consisting of the late Villafranchian to Epivillafranchian faunas younger than $\sim 2.0-1.9 \mathrm{Ma}$ and B2 including those faunas that are at or slightly after the middle/late Villafranchian boundary, at ca. 2.0 (Fonelas P-1 and Gerakarou-1). Subcluster B1 is separated into B1.1 of the late Villafranchian to Epivillafranchian faunas of Europe and B1.2 of Dmanisi. The former is further divided into B1.1.1 ( 2.0-1.5 Ma) and B1.1.2 (after 1.6-1.5 Ma). This distinction signifies the small-scale reorganization of the faunas at the genus level during the middle part of the late Villafranchian, leading to the faunas (B1.1.2) of the second part of the late Villafranchian and the Epivillafranchian, which have "lost" middle Villafranchian relics and have mostly "renewed" their faunal elements. B1.1.1 is separated into B1.1.1a, which includes the 2.0-1.8 Ma faunas of Poggio Rosso and Pantalla (both within Olivola/Tasso FUs $[1,81]$; and B1.1.1b, with the faunas dated between $\sim 1.8$ and $\sim 1.5 \mathrm{Ma}$. B1.1.1b, including TSR, represents the time interval, which documents the co-existence of Leptobos and Bison, the earliest occurrences of Praemegaceros in Europe, and 
is overall characterized by the mixture of middle ("archaic") Villafranchian components and "modern" late Villafranchian newcomers.

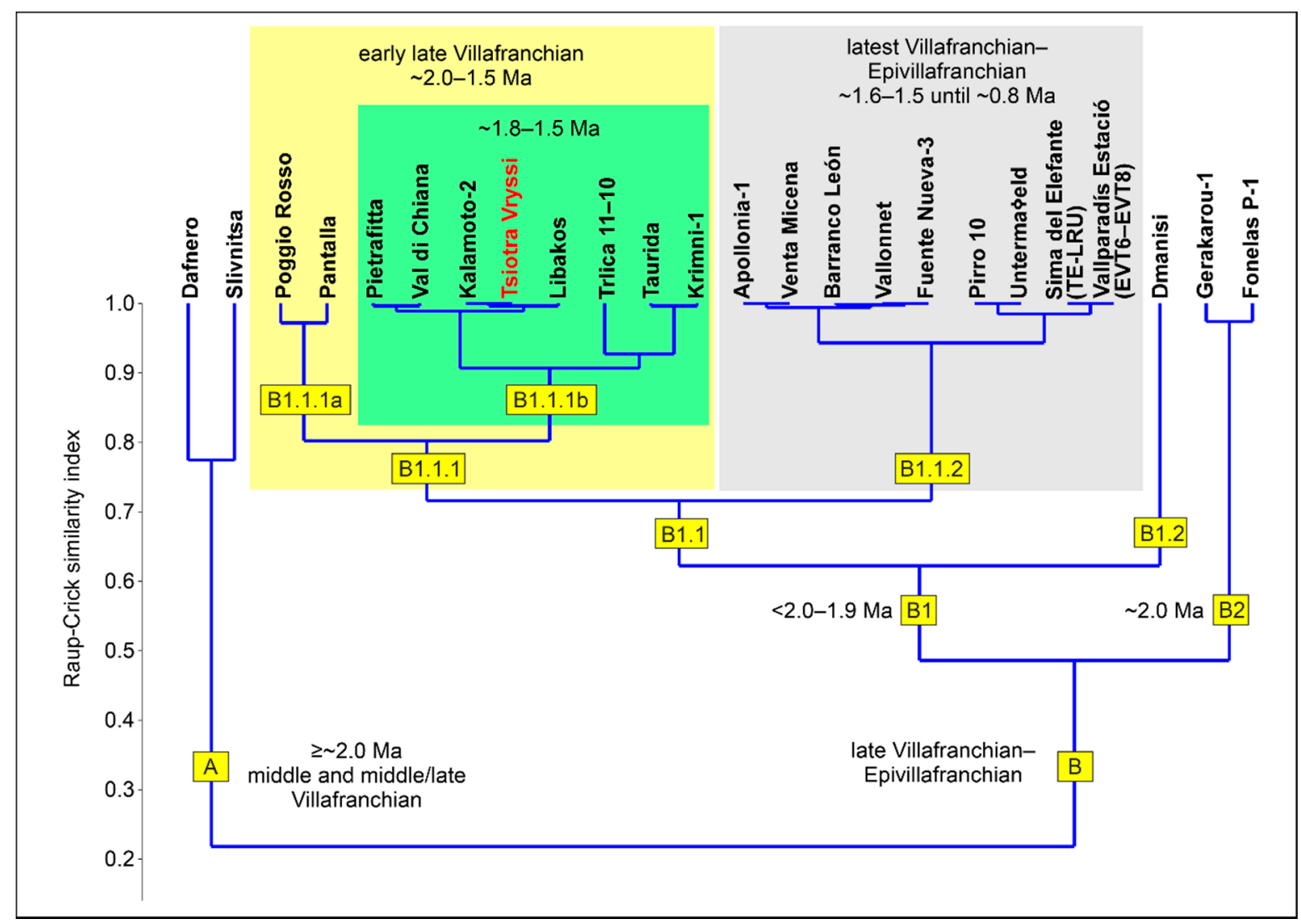

Figure 8. Hierarchical cluster analysis at the genus level showing the faunal similarities among selected middle Villafranchian to Epivillafranchian mammal assemblages of western Eurasia.

Considering all biochronological data, TSR is younger than the middle Villafranchian $(\sim 2.6-2.0 \mathrm{Ma})$ faunas and older than the latest Villfranchian and Epivillafranchian ones ( 1.5-0.8 Ma, e.g, the Orce sites, Apollonia-1, Pirro Nord, Untermassfeld, and Vallonnet). On the basis of the large mammals, a biochronological age between $\sim 1.8$ and 1.6-1.5 Ma is expected for TSR.

\section{Discussion}

\subsection{Age Estimation: Age Constraints}

The minimum burial ages $(1.88 \pm 0.16 \mathrm{Ma}, 2.10 \pm 0.18 \mathrm{Ma}$, and $1.98 \pm 0.18 \mathrm{Ma})$ provided by the cosmogenic radionuclide method indicate that the normal magnetic polarity interval encompassing Geo $2 b$ and the bottom part of Geo $2 a$ correlates to the Olduvai subchron (1.95-1.78 Ma, C2n). As a result, the whole magnetic polarity sequence corresponds to the late part of the Olduvai and the early part of the succeeding Matuyama Chron, whose base is currently dated to $1.78 \mathrm{Ma}$ [82]. Therefore, an age younger than 1.78 Ma is indicated for the fossiliferous layer (the bulk of Geo 2a), which was deposited during reverse polarity chron $\mathrm{C} 1 \mathrm{r}$. These results are in very good agreement with the biochronological data, which also indicate an upper age limit at $1.5 \mathrm{Ma}$ for the fossil accumulation. Therefore, an age between 1.78 and $~ 1.5 \mathrm{Ma}$ (within the first part of the late Villafranchian) is proposed for the TSR fauna (Figure 9). 


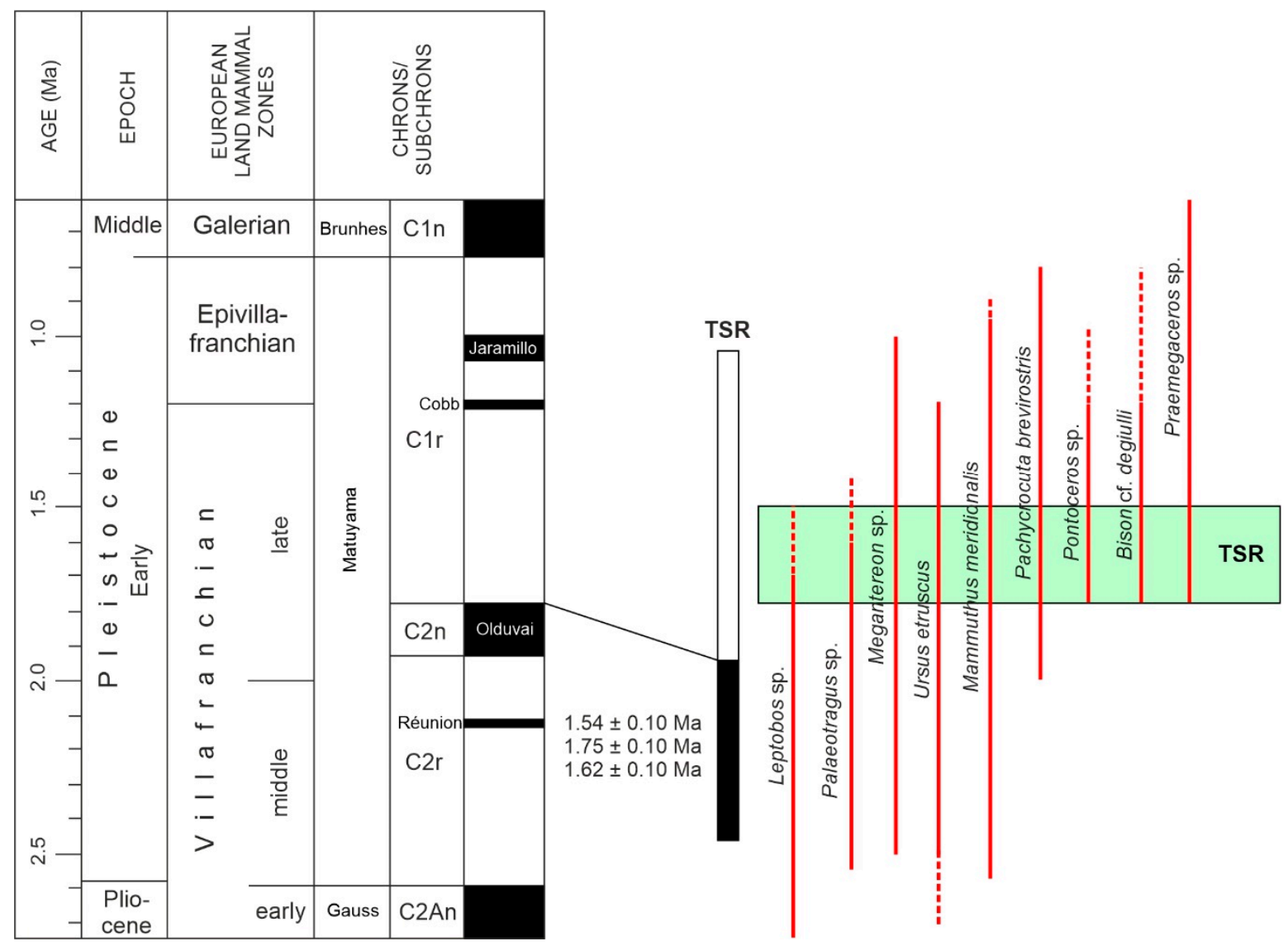

Figure 9. Correlation with the geomagnetic polarity time scale (GPTS) [82], simple burial ages provided by cosmogenic radionuclides, and biochronological range of selected large mammals from Tsiotra Vryssi.

\subsection{Placement of TSR within the Greek and European Context}

The TSR fauna lacks typical middle Villafranchian ( 2.6-2.0 Ma) large mammal associations, including the cervids Croizetoceros, Metacervocerus, and Eucladoceros; the bovids Gazella, Gazellospira, and Gallogoral; the canid Nyctereutes; and the hyaenids Chasmaporthetes and Pliocrocuta, present in the Saint-Vallier FU, Varshets (Bulgaria), as well as in the Greek fossil record, for example, in Dafnero, Sesklo, Vatera, and Volax $[1,22,56,83]$. TSR also appears younger than the "Canis" or "Panthera" sites of the Costa San Giacomo FU, Senéze (France), La Puebla de Valverde (Spain) and Slivnitsa, correlated close to the middle/late Villafranchian boundary, and which preserve most of the genera mentioned above $[56,61,81,84]$. However, TSR retains some middle Villafranchian taxa, which also survived until the beginning of the late Villafranchian, such as Leptobos and Palaeotragus. On the other hand, the TSR fauna includes several late Villafranchian newcomers, such as Pachycrocuta, Pontoceros, Bison and Praemegaceros. The association Palaeotragus + Praemegaceros (+ Leptobos in [85]) is so far only recorded in Fîntîna lui Mitilan (Romania, [86]), the association Leptobos + Bison + Pontoceros + Praemegaceros + two Equus species is documented to date only in Trlica 11-10 [75], while the association Leptobos + Bison + Pontoceros + two Equus species in Taurida Cave [67]. TSR is also close to Dmanisi, whose faunal record includes Palaeotragus, Bison, Pontoceros, Praemegaceros, and two Equus species [11]. With respect to localities of the central/western sector of the Mediterranean region, TSR is chronologically younger than Fonelas-P1, Poggio Rosso, and Upper Valdarno localities, all correlated to the beginning of the late Villafranchian (ca. 2.0-1.8 Ma), and it is older than Venta Micena, Pirro Nord, Fuente Nueva-3, and Barranco León, collectively dated after ca. 1.6-1.5 Ma, fitting best with the Farneta FU of Italy. 
Within the regional faunal succession, TSR is younger than Gerakarou 1 yielding the late Villafranchian "marker" Pachycrocuta brevirostris, but otherwise still retaining a more "middle Villafranchian character" in its fauna including the bovid Gazella (in Italy not later than the Costa San Giacomo FU [79,87]) and the suid Sus strozzi (see [88]). On the other hand, TSR is older than Apollonia 1, where middle Villafranchian relics are absent, and typical late Villafranchian components are present, such as Canis apolloniensis (Canis ex gr. mosbachensis), Bison, Praemegaceros, and Pontoceros, accompanied by various caprines/ovibovines [22], the latter, so far, absent from TSR. The current data indicate that TSR is perhaps chronologically close (although faunal and perhaps chronological differences do exist) with Krimni-1 and Kalamoto-2, where leptobovine bovids also coexist with bisons. Outside the Mygdonia Basin, Libakos (Aliakmon Basin) might be of comparable age to TSR. Libakos has yielded Leptobos, Palaeotragus, Pachycrocuta, Pontoceros, Equus altidens, and two Canis species, in association, however, with the more "modern" Hippopotamus antiquus, and the cervids Praedama savini and Dama vallonnetensis [22,89].

\section{Conclusions}

Cosmogenic radionuclide dating provides numerical age constraints on the normal polarity detected from the magnetostratigraphic analysis below the fossiliferous layer, correlating it to the Olduvai Subchron. The reverse polarity interval identified in the fossiliferous layer, combined with the biochronological data, indicate that the TSR sediments were deposited during the early part of the Matuyama Chron, between 1.78 and 1.5 Ma. Overall, TSR presents faunal similarities with Dmanisi, the Farneta FU, Trlica 11-10, Taurida, and the Greek faunas of Libakos, Krimni-1, and Kalamoto-2. Our results not only provide constraints for the age of the local mammal faunal succession, but also help to improve correlations on a broader scale between northern Mediterranean and peri-Black Sea sites, thus, leading to more accurate biogeographic, palaeoecological, and taphonomic interpretations during a crucial interval of time for mammal/hominin migrations and faunal turnovers.

The dating of TSR at ca. 1.78-1.5 Ma places the site close to (or shortly after) the age of Dmanisi, which documents the earliest presence of hominins in western Eurasia. Additionally, this interval records the last occurrences of a number of Villafranchian taxa, as well as the onset of a gradual displacement of other taxa by large mammals that characterize the following Epivillafranchian and Galerian large mammal ages [1,7,9]. Inter-regional differences in the timing and extent of faunal renewals, dispersals, and changes in the structure of mammal palaeocommunities reflect the variability in biotic responses to ecological stimuli according to the geographic setting and prevailing environmental conditions $[9,90]$. Chronological frameworks serve as the building blocks that allow us to assess potential synchroneity, asynchrony, or diachrony in faunal dynamics. Such detailed studies have been lacking until recently for the Pleistocene of the Greek peninsula. Together with the current investigations for the middle Villafranchian [31,66], our study contributes to filling this gap by providing, for the first time, palaeomagnetic and radiometric constraints to a late Villafranchian locality in the Balkans, and in the Mygdonia Basin in particular, which is one of the most important and richest fossiliferous basins in southeastern Europe. Further refinement of the chronostratigraphic framework of the Mygdonia Basin would provide a better understanding of faunal changes within this sedimentary basin and help calibrate biochronological correlations with other, supra-regional faunal complexes.

Author Contributions: Conceptualization, G.E.K., D.S.K., V.T., G.D.K., and K.H.; methodology, G.E.K., D.S.K., M.M. (Matteo Maron), M.S., T.A.E., E.A., M.M. (Mattia Marini), and G.M.; software, G.E.K., M.M. (Matteo Maron), and M.M. (Mattia Marini); validation, G.E.K., D.S.K., M.M. (Matteo Maron), M.S., T.A.E., E.A., M.M. (Mattia Marini), V.T., G.M., G.D.K., and K.H.; formal analysis, G.E.K., D.S.K., M.M. (Matteo Maron), M.S., T.A.E., E.A., and M.M. (Mattia Marini); data curation, G.E.K., D.S.K., M.M. (Matteo Maron), M.S., T.A.E., E.A., M.M. (Mattia Marini), G.M., and G.D.K.; writing—original draft preparation, G.E.K., D.S.K., M.M. (Matteo Maron), M.S., E.A., M.M. (Mattia Marini), and V.T.; writing-review and editing, G.E.K., D.S.K., M.M. (Matteo Maron), M.S., T.A.E., 
E.A., M.M. (Mattia Marini), V.T., G.M., G.D.K., and K.H.; visualization, G.E.K., M.M. (Matteo Maron), and M.M. (Mattia Marini); project administration, G.E.K., D.S.K., V.T., G.D.K., and K.H.; funding acquisition, K.H. All authors have read and agreed to the published version of the manuscript.

Funding: This research was supported by the European Research Council STG no. 283503 (PaGE) and the European Research Council CoG 724703 (CROSSROADS), both awarded to K. Harvati (University of Tübingen).

Data Availability Statement: Data is contained within the article.

Acknowledgments: We are grateful to D. Giusti, N. Thompson (University of Tübingen) and all the field team members for their valuable contribution. We thank the four reviewers for their constructive comments and suggestions.

Conflicts of Interest: The authors declare no conflict of interest.

\section{References}

1. Rook, L.; Martínez-Navarro, B. Villafranchian: The long story of a Plio-Pleistocene European large mammal biochronologic unit. Quat. Int. 2010, 219, 134-144. [CrossRef]

2. Martínez-Navarro, B. Early Pleistocene faunas of Eurasia and hominin dispersals. In Out of Africa I. The first hominin colonization of Eurasia; Fleagle, J.G., Shea, J.J., Grine, F.E., Baden, A.L., Leakey, R.E., Eds.; Springer: Dordrecht, The Netherlands, 2010; pp. 207-224.

3. Napoleone, G.; Albianelli, A.; Azzaroli, A.; Bertini, A.; Magi, M.; Mazzini, I. Calibration of the upper Valdarno basin to the Plio-Pleistocene for correlating the Apennine continental sequences. Il Quaternario 2003, 16, 131-166.

4. Kahlke, R.D. Late Early Pleistocene European large mammals and the concept of an Epivillafranchian biochron. In Late Neogene and Quaternary Biodiversity and Evolution: Regional Developments and Interregional Correlations. Vol. II. Proceedings of the 18th International Senckenberg Conference (VI International Palaeontological Colloquium in Weimar); Kahlke, R.D., Maul, L.C., Mazza, P., Eds.; Courier Forschungsinstitut Senckenberg: Frankfurt a. M., Germany, 2007; Volume 259, pp. 265-278.

5. Palombo, M.R. Large mammals faunal dynamics in Southwestern Europe during the late Early Pleistocene: Implications for the biochronological assessment and correlation of mammalian faunas. Alpine Mediterr. Quat. 2016, 29, 143-168.

6. Bellucci, L.; Sardella, R.; Rook, L. Large mammal biochronology framework in Europe at Jaramillo: The Epivillafranchian as a formal biochron. Quat. Int. 2015, 389, 84-89. [CrossRef]

7. Kahlke, R.D.; García, N.; Kostopoulos, D.S.; Lacombat, F.; Lister, A.M.; Mazza, P.P.A.; Spassov, N.; Titov, V.V. Western Palaearctic palaeoenvironmental conditions during the Early and early Middle Pleistocene inferred from large mammal communities, and implications for hominin dispersal in Europe. Quat. Sci. Rev. 2011, 30, 1368-1395. [CrossRef]

8. Leroy, S.A.G.; Arpe, K.; Mikolajewicz, U. Vegetation context and climatic limits of the Early Pleistocene hominin dispersal in Europe. Quat. Sci. Rev. 2011, 30, 1448-1463. [CrossRef]

9. Palombo, M.R. Deconstructing mammal dispersals and faunal dynamics in SW Europe during the Quaternary. Quat. Sci. Rev. 2014, 96, 50-71. [CrossRef]

10. Ferring, R.; Oms, O.; Agustí, J.; Berna, F.; Nioradze, M.; Shelia, T.; Tappen, M.; Vekua, A.; Zhvania, D.; Lordkipanidze, D. Earliest human occupations at Dmanisi (Georgian Caucasus) dated to 1.85-1.78 Ma. Proc. Natl. Acad. Sci. USA 2011, 108, 10432-10436. [CrossRef]

11. Lordkipanidze, D.; Jashashvili, T.; Vekua, A.; de Leon, M.S.P.; Zollikofer, C.P.E.; Rightmire, G.P.; Pontzer, H.; Ferring, R.; Oms, O.; Tappen, M.; et al. Postcranial evidence from early Homo from Dmanisi, Georgia. Nature 2007, 449, 305-310. [CrossRef]

12. Palombo, M.R. Faunal dynamics in SW Europe during the late Early Pleistocene: Palaeobiogeographical insights and biochronological issues. In European Early Pleistocene Biogeography and Ecology Based on the Mammal Record: Case Studies and Preliminary Syntheses; Kostopoulos, D.S., Konidaris, G., Tesakov, A., van den Hoek Ostende, L.W., Rook, L., Eds.; Comptes Rendus Palevol: Amsterdam, The Netherlands, 2018; Volume 17, pp. 247-261.

13. Muttoni, G.; Scardia, G.; Kent, D.V. Early hominins in Europe: The Galerian migration hypothesis. Quat. Sci. Rev. 2018, 180, 1-29. [CrossRef]

14. Palombo, M.R. Biochronology of terrestrial mammals and Quaternary subdivisions: A case study of large mammals from the Italian peninsula. Il Quaternario 2009, 22, 291-306.

15. Palombo, M.R. Discrete dispersal bioevents of large mammals in Southern Europe in the post-Olduvai Early Pleistocene: A critical overview. Quat. Int. 2017, 431, 3-19. [CrossRef]

16. Sakellariou-Mane, E.; Psilovikos, A.; Koufos, G. Contribution to the study of Villafranchian in Northern Chalkidiki (Macedonia, Greece). Sci. Annals, Fac. Phys. Mathem., Univ. Thessaloniki 1979, 19, 279-293.

17. Zamanis, A.; Faugères, L.; Bonis, L.d.; Fountoulis, D.; Simeakis, C.; Panayotis, I.; Dimitrakopoulos, R.; Mercier, J.L. Découverte d'une faune de Mammifères du Quaternaire ancien dans les formations du lac Langhada (Macédoine centrale, Grèce). Implications néotectoniques. C. R. Acad. Sci. Paris 1980, 291, 813-816.

18. Koufos, G.D.; Melentis, J.K. New data from the Villafranchian mammal locality of Gerakarou (Macedonia-Greece). Prak. Akad. Ath. 1983, 58, 185-191. 
19. Koufos, G.D.; Syrides, G.E.; Kostopoulos, D.S.; Koliadimou, K.K. Preliminary results about the stratigraphy and the palaeoenvironment of Mygdonia Basin, Macedonia, Greece. Geobios 1995, M.S. 18, 243-249. [CrossRef]

20. Tsoukala, E.; Chatzopoulou, K. A new Early Pleistocene (latest Villafranchian) site with mammals in Kalamotó (Mygdonia Basin, Macedonia, Greece) - Preliminary report. Mitt. Komm. Quartärforsch. Österr. Akad. Wiss. 2005, 14, $213-233$.

21. Konidaris, G.E.; Tourloukis, V.; Kostopoulos, D.S.; Thompson, N.; Giusti, D.; Michailidis, D.; Koufos, G.D.; Harvati, K. Two new vertebrate localities from the Early Pleistocene of Mygdonia Basin (Macedonia, Greece): Preliminary results. C. R. Palevol 2015, 14, 353-362. [CrossRef]

22. Koufos, G.D.; Kostopoulos, D.S. The Plio-Pleistocene large mammal record of Greece: Implications for early human dispersals into Europe. In Paleoanthropology of the Balkans and Anatolia; Harvati, K., Roksandic, M., Eds.; Springer: Dordrecht, The Netherlands, 2016; pp. 269-280.

23. Kostopoulos, D.S.; Vassiliadou, K.; Koufos, G.D. The beginning of Pleistocene in the Balkan area according to the mammal record; palaeozoogeographical approach. Ann. Géol. Pays Hellén. 2002, 39, 253-278.

24. Spassov, N. Southeastern Europe as a route for the earliest dispersal of Homo toward Europe: Ecological conditions and the timing of the first human occupation of Europe. In Paleoanthropology of the Balkans and Anatolia; Harvati, K., Roksandic, M., Eds.; Springer: Dordrecht, The Netherlands, 2016; pp. 281-290.

25. Tourloukis, V.; Harvati, K. The Palaeolithic record of Greece: A synthesis of the evidence and a research agenda for the future. Quat. Int. 2018, 66, 48-65. [CrossRef]

26. Harvati, K.; Panagopoulou, E.; Runnels, C. The paleoanthropology of Greece. Evol. Anthropol. 2009, 18, 131-143. [CrossRef]

27. Harvati, K.; Röding, C.; Bosman, A.M.; Karakostis, F.A.; Grün, R.; Stringer, C.; Karkanas, P.; Thompson, N.C.; Koutoulidis, V.; Moulopoulos, L.A.; et al. Apidima Cave fossils provide earliest evidence of Homo sapiens in Eurasia. Nature 2019, 571, 500-504. [CrossRef]

28. Athanassiou, A. Pleistocene vertebrates from the Kyparíssia lignite mine, Megalopolis Basin, S. Greece: Rodentia, Carnivora, Proboscidea, Perissodactyla, Ruminantia. Quat. Int. 2018, 497, 198-221. [CrossRef]

29. Athanassiou, A.; Michailidis, D.; Vlachos, E.; Tourloukis, V.; Thompson, N.; Harvati, K. Pleistocene vertebrates from the Kyparíssia lignite mine, Megalopolis Basin, S. Greece: Testudines, Aves, Suiformes. Quat. Int. 2018, 497, 178-197. [CrossRef]

30. Konidaris, G.E.; Athanassiou, A.; Tourloukis, V.; Thompson, N.; Giusti, D.; Panagopoulou, E.; Harvati, K. The skeleton of a straight-tusked elephant (Palaeoloxodon antiquus) and other large mammals from the Middle Pleistocene butchering locality Marathousa 1 (Megalopolis Basin, Greece): Preliminary results. Quat. Int. 2018, 497, 65-84. [CrossRef]

31. Benammi, M.; Aidona, E.; Merceron, G.; Koufos, G.D.; Kostopoulos, D.S. Magnetostratigraphy and chronology of the Lower Pleistocene primate bearing Dafnero fossil site, N. Greece. Quaternary 2020, 3, 22. [CrossRef]

32. Psilovikos, A.A. Palaeogeographic development of the basin and lake of Mygdonia (Langada-Volvi area), Greece. Ph.D. Thesis, Aristotle University of Thessaloniki, Thessaloniki, Greece, 1977.

33. Giusti, D.; Konidaris, G.E.; Tourloukis, V.; Marini, M.; Maron, M.; Zerboni, A.; Thompson, N.; Koufos, G.D.; Kostopoulos, D.S.; Harvati, K. Recursive anisotropy: A spatial taphonomic study of the Early Pleistocene vertebrate assemblage of Tsiotra Vryssi, Mygdonia Basin, Greece. Boreas 2019, 48, 713-730.

34. Konidaris, G.E.; Kostopoulos, D.S.; Koufos, G.D.; Tourloukis, V.; Harvati, K. Tsiotra Vryssi: A new vertebrate locality from the Early Pleistocene of Mygdonia Basin (Macedonia, Greece). In Proceedings of the XIV Annual Meeting of the European Association of Vertebrate Palaeontologists, Haarlem, The Netherlands, 6-10 July 2016; p. 37.

35. Kostopoulos, D.S.; Maniakas, I.; Tsoukala, E. Early bison remains from Mygdonia Basin (Northern Greece). Geodiversitas 2018, 40, 283-319. [CrossRef]

36. Koufos, G.D.; Konidaris, G.E.; Harvati, K. Revisiting Ursus etruscus (Carnivora, Mammalia) from the Early Pleistocene of Greece with description of new material. Quat. Int. 2018, 497, 222-239.

37. Granger, D.E.; Kirchner, J.W.; Finkel, R.C. Quaternary downcutting rate of the New River, Virginia, measured from differential decay of cosmogenic ${ }^{26} \mathrm{Al}$ and ${ }^{10} \mathrm{Be}$ in cave-deposited alluvium. Geology 1997, 25, 107-110. [CrossRef]

38. Granger, D.E.; Muzikar, P.F. Dating sediment burial with in situ-produced cosmogenic nuclides: Theory, techniques, and limitations. Earth Planet. Sci. Lett. 2001, 188, 269-281. [CrossRef]

39. Granger, D.E. Cosmogenic nuclide burial dating in archaeology and paleoanthropology. In Treatise on Geochemistry, 2nd ed.; Holland, H.D., Turekian, K.K., Eds.; Elsevier: Amsterdam, The Netherlands, 2014; pp. 81-97.

40. Schaller, M.; Ehlers, T.A.; Stor, T.; Torrent, J.; Lobato, L.; Christl, M.; Vockenhuber, C. Timing of European fluvial terrace formation and incision rates constrained by cosmogenic nuclide dating. Earth Planet. Sci. Lett. 2016, 451, 221-231. [CrossRef]

41. Nishiizumi, K. Preparation of ${ }^{26}$ Al AMS standards. Nucl. Instrum. Methods Phys. Res. B 2004, 223-224, 388-392. [CrossRef]

42. Nishiizumi, K.; Imamura, M.; Caffee, M.W.; Southon, J.R.; Finkel, R.C.; McAninch, J. Absolute calibration of ${ }^{10}$ Be AMS standards. Nucl. Instrum. Methods Phys. Res. B 2007, 258, 403-413. [CrossRef]

43. Norris, T.L.; Gancarz, A.J.; Rokop, D.J.; Thomas, K.W. Half-life of ${ }^{26}$ Al. J. Geophys. Res. Solid Earth 1983, 88, B331-B333. [CrossRef]

44. Chmeleff, J.; von Blanckenburg, F.; Kossert, K.; Jakob, D. Determination of the ${ }^{10}$ Be half-life by multicollector ICP-MS and liquid scintillation counting. Nucl. Instrum. Methods Phys. Res. B 2010, 268, 192-199. [CrossRef]

45. Korschinek, G.; Bergmaier, A.; Faestermann, T.; Gerstmann, U.C.; Knie, K.; Rugel, G.; Wallner, A.; Dillmann, I.; Dollinger, G.; von Gostomski, C.L.; et al. A new value for the half-life of ${ }^{10}$ Be by Heavy-Ion Elastic Recoil Detection and liquid scintillation counting. Nucl. Instrum. Methods Phys. Res. B 2010, 268, 187-191. [CrossRef] 
46. Braucher, R.; Merchel, S.; Borgomano, J.; Bourlès, D.L. Production of cosmogenic radionuclides at great depth: A multi element approach. Earth Planet. Sci. Lett. 2011, 309, 1-9. [CrossRef]

47. Borchers, B.; Marrero, S.; Balco, G.; Caffee, M.; Goehring, B.; Lifton, N.; Nishiizumi, K.; Phillips, F.; Schaefer, J.; Stone, J. Geological calibration of spallation production rates in the CRONUS-Earth project. Quat. Geochronol. 2016, 31, 188-198. [CrossRef]

48. Marrero, S.M.; Phillips, F.M.; Borchers, B.; Lifton, N.; Aumer, R.; Balco, G. Cosmogenic nuclide systematics and the CRONUScalc program. Quat. Geochronol. 2016, 31, 160-187. [CrossRef]

49. Lifton, N.; Sato, T.; Dunai, T.J. Scaling in situ cosmogenic nuclide production rates using analytical approximations to atmospheric cosmic-ray fluxes. Earth Planet. Sci. Lett. 2014, 386, 149-160. [CrossRef]

50. Hammer, Ø.; Harper, D.A.T.; Ryan, P.D. PAST: Paleontological statistics software package for education and data analysis. Palaeontol. Electron. 2001, 4, 1-9.

51. Hammer, Ø.; Harper, D.A.T. Paleontological data analysis; Blackwell Publishing: Oxford, UK, 2006; p. 351.

52. Arribas, A.; Garrido, G.; Viseras, C.; Soria, J.M.; Pla, S.; Solano, J.G.; Garcés, M.; Beamud, E.; Carrión, J.S. A mammalian lost world in Southwest Europe during the Late Pliocene. PLoS ONE 2009, 4, e7127. [CrossRef] [PubMed]

53. Kahlke, R.D. Die Unterpleistozäne Komplexfundstelle Untermaßfeld-Zusammenfassung des Kenntnisstandes sowie synthetische Betrachtungen zu Genesemodell, Paläoökologie und Stratigraphie. In Das Pleistozän von Untermaßfeld bei Meiningen (Thüringen), Teil 3; Kahlke, R.D., Ed.; Monographien des Römisch-Germanischen Zentralmuseums Mainz, Dr. Rudolf Habelt: Bonn, Germany, 2001; pp. 931-1030.

54. Kahlke, R.D. (Ed.) The Pleistocene of Untermassfeld near Meiningen (Thüringen, Germany). Part 4; Monographien des RömischGermanischen Zentralmuseums Mainz: Mainz, Germany, 2020; Volume 40.

55. Koufos, G.D. The Villafranchian mammalian faunas and biochronology of Greece. Boll. Soc. Paleontol. Ital. 2001, 40, $217-223$.

56. Spassov, N. The Plio-Pleistocene vertebrate fauna in South-Eastern Europe and the megafaunal migratory waves from the east to Europe. Rev. de Paléobiologie 2003, 22, 197-229.

57. Mazza, P.P.A.; Bertini, A.; Magi, M. The Late Pliocene site of Poggio Rosso (Central Italy): Taphonomy and paleoenvironment. Palaios 2004, 19, 227-248. [CrossRef]

58. Pavia, M.; Zunino, M.; Coltorti, M.; Angelone, C.; Arzarello, M.; Bagnus, C.; Bellucci, L.; Colombero, S.; Marcolini, F.; Peretto, C.; et al. Stratigraphical and palaeontological data from the Early Pleistocene Pirro 10 site of Pirro Nord (Puglia, south eastern Italy). Quat. Int. 2012, 267, 40-55. [CrossRef]

59. Huguet, R.; Saladié, P.; Cáceres, I.; Díez, C.; Rosell, J.; Bennàsar, M.; Blasco, R.; Esteban-Nadal, M.; Gabucio, M.J.; RodríguezHidalgo, A.; et al. Successful subsistence strategies of the first humans in south-western Europe. Quat. Int. 2013, 295, 168-182. [CrossRef]

60. Madurell-Malapeira, J.; Minwer-Barakat, R.; Alba, D.M.; Garcés, M.; Gómez, M.; Aurell-Garrido, J.; Ros-Montoya, S.; Moyà-Solà, S.; Berástegui, X. The Vallparadís section (Terrassa, Iberian Peninsula) and the latest Villafranchian faunas of Europe. Quat. Sci. Rev. 2010, 29, 3972-3982. [CrossRef]

61. Madurell-Malapeira, J.; Ros-Montoya, S.; Espigares, M.P.; Alba, D.M.; Aurell-Garrido, J. Villafranchian large mammals from the Iberian Peninsula: Paleobiogeography, paleoecology and dispersal events. J. Iber. Geol. 2014, 167-178. [CrossRef]

62. Medin, T.; Martínez-Navarro, B.; Rivals, F.; Madurell-Malapeira, J.; Ros-Montoya, S.; Espigares, M.P.; Figueirido, B.; Rook, L.; Palmqvist, P. Late Villafranchian Ursus etruscus and other large carnivorans from the Orce sites (Guadix-Baza basin, Andalusia, southern Spain): Taxonomy, biochronology, paleobiology, and ecogeographical context. Quat. Int. 2017, 431, 20-41. [CrossRef]

63. Vislobokova, I.A.; Agadjanyan, A.K. New data on age of the Pleistocene fauna from the Trlica locality (Montenegro, Central Balkans) and its correlation with other faunas of Europe. Stratigr. Geol. Correl. 2016, 24, 188-202. [CrossRef]

64. Michel, V.; Shen, C.C.; Woodhead, J.; Hu, H.M.; Wu, C.C.; Moullé, P.É.; Khatib, S.; Cauche, D.; Moncel, M.H.; Valensi, P.; et al. New dating evidence of the early presence of hominins in Southern Europe. Sci. Rep. 2017, 7, 10074. [CrossRef]

65. Cherin, M.; D'Allestro, V.; Masini, F. New bovid remains from the Early Pleistocene of Umbria (Italy) and a reappraisal of Leptobos merlai. J. Mamm. Evol. 2019, 26, 201-224. [CrossRef]

66. Kostopoulos, D.S.; Aidona, E.; Benammi, M.; Gkeme, A.; Grasset, L.; Guy, F.; Koufos, G.D.; Kynigopoulou, Z.; Le Maitre, A.; Novello, A.; et al. The Lower Pleistocene primate-bearing fossil site of Dafnero (W. Macedonia, Greece): New data from classic and innovative approaches. In Proceedings of the 15th International Congress of the Geological Society of Greece, Athens, Greece, 22-24 May 2019.

67. Lopatin, A.V.; Vislobokova, I.A.; Lavrov, A.V.; Startsev, D.B.; Gimranov, D.O.; Zelenkov, N.V.; Maschenko, E.N.; Sotnikova, M.V.; Tarasenko, K.K.; Titov, V.V. The Taurida cave, a new locality of Early Pleistocene vertebrates in Crimea. Dokl. Biol. Sci. 2019, 485, 40-43. [CrossRef] [PubMed]

68. Lowrie, W. Identification of ferromagnetic minerals in a rock by coercivity and unblocking temperature properties. Geophys. Res. Lett. 1990, 17, 159-162. [CrossRef]

69. McFadden, P.L.; McElhinny, M.W. Classification of the reversal test in palaeomagnetism. Geophys. J. Int. 1990, 103, 725-729. [CrossRef]

70. Sotnikova, M.; Rook, L. Dispersal of the Canini (Mammalia, Canidae: Caninae) across Eurasia during the Late Miocene to Early Pleistocene. Quat. Int. 2010, 212, 86-97. [CrossRef] 
71. Cherin, M.; Bertè, D.F.; Rook, L.; Sardella, R. Re-defining Canis etruscus (Canidae, Mammalia): A new look into the evolutionary history of early Pleistocene dogs resulting from the outstanding fossil record from Pantalla (Italy). J. Mamm. Evol. 2014, 21, 95-110. [CrossRef]

72. Koufos, G.D. The Pleistocene carnivores of the Mygdonia basin (Macedonia, Greece). Ann. de Paléontol. 1992, 78, $205-257$.

73. Spassov, N. Biochronology and zoogeographic affinities of the Villafranchian faunas of Bulgaria and South Europe. Hist. Nat. Bulgarica 2000, 12, 89-128.

74. Masini, F.; Sala, B. Large- and small-mammal distribution patterns and chronostratigraphic boundaries from the Late Pliocene to the Middle Pleistocene of the Italian peninsula. Quat. Int. 2007, 160, 43-56. [CrossRef]

75. Vislobokova, I.A.; Agadjanian, A.K. New data on large mammals of the Pleistocene Trlica fauna, Montenegro, the Central Balkans. Paleontol. J. 2015, 49, 651-667. [CrossRef]

76. Vislobokova, I.A.; Titov, V.V.; Lavrov, A.V.; Gimranov, D.O.; Startsev, D.B.; Tasasenko, K.K. Early Pleistocene spiral-horned antelopes (Artiodactyla, Bovidae) from the Taurida Cave (Crimea, Russia). Paleontol. J. 2020, 54, 81-90. [CrossRef]

77. Abbazzi, L. La fauna de cérvidos de Barranco León y Fuente Nueva-3. In Ocupaciones Humanas en el Pleistoceno Inferior y Medio de la Cuenca de Guadix-Baza; Toro, I., Martínez-Navarro, B., Agustí, J., Eds.; Consejería de Cultura, Junta de Andalucía, Arqueología Monografías: Sevilla, Spain, 2010; pp. 273-290.

78. Athanassiou, A. New giraffid (Artiodactyla) material from the Lower Pleistocene locality of Sésklo (SE Thessaly, Greece): Evidence for an extension of the genus Palaeotragus into the Pleistocene. Zitteliana B 2014, 32, 71-89.

79. Masini, F.; Palombo, M.R.; Rozzi, R. A reappraisal of the Early to Middle Pleistocene Italian Bovidae. Quat. Int. 2013, 288, 45-62. [CrossRef]

80. Sorbelli, L.; Madurell-Malapeira, J.; Prat-Vericat, M.; Azzarà, B.; Romi, P.; Gentili, S.; Cherin, M. Primitive Bison from the late Villafranchian site of Pietrafitta (Italy). In Proceedings of the Invertebrate and Vertebrate Paleontology day (IVPday), Pisa, Italy, 17-20 November 2020; pp. 112-116.

81. Sardella, R.; Bellucci, L.; Bona, F.; Cherin, M.; Iurino, D.A.; Rook, L. Before and after the earliest Homo dispersal in Europe: Evidence from the early Pleistocene sites of the Italian Peninsula. In European Early Pleistocene Biogeography and Ecology Based on the Mammal Record: Case Studies and Preliminary Syntheses; Kostopoulos, D.S., Konidaris, G., Tesakov, A., van den Hoek Ostende, L.W., Rook, L., Eds.; Comptes Rendus Palevol: Amsterdam, The Netherlands, 2018; Volume 17, pp. $287-295$.

82. Cohen, K.M.; Gibbard, P.L. Global chronostratigraphical correlation table for the last 2.7 million years, version 2019 QI-500. Quat. Int. 2019, 500, 20-31. [CrossRef]

83. Guérin, C.; Faure, M.; Argant, A.; Argant, J.; Crégut-Bonnoure, É.; Debard, É.; Delson, E.; Eisenmann, V.; Hugueney, M.; Limondin-Lozouet, N.; et al. Le gisement pliocène supérieur de Saint-Vallier (Drôme, France): Synthèse biostratigraphique et paléoécologique. Geobios 2004, 37, S349-S360.

84. Delson, E.; Faure, M.; Guerin, C.; Aprile, L.; Argant, J.; Blackwell, B.A.B.; Debard, E.; Harcourt-Smith, W.; Martin-Suarez, E.; Monguillon, A.; et al. Franco-American renewed research at the Late Villafranchian locality of Senèze (Haute-Loire, France). Cour. Forsch.-Inst. Senckenberg 2006, 256, 275-290.

85. Radulescu, C.; Samson, P.M. Biochronology and evolution of the Early Pliocene to the Early Pleistocene mammalian faunas of Romania. Boll. Soc. Paleontol. Ital. 2001, 40, 285-291.

86. Terhune, C.E.; Curran, S.; Croitor, R.; Drăgușin, V.; Gaudin, T.; Petculescu, A.; Robinson, C.; Robu, M.; Werdelin, L. Early Pleistocene fauna of the Olteţ River Valley of Romania: Biochronological and biogeographic implications. Quat. Int. 2020, 553, 14-33. [CrossRef]

87. Bellucci, L.; Sardella, R. The last Antilopini bovids from the Early Pleistocene of Italy. Quat. Int. 2015, 357, 245-252. [CrossRef]

88. Martínez-Navarro, B.; Madurell-Malapeira, J.; Ros-Montoya, S.; Espigares, M.P.; Medin, T.; Hortolà, P.; Palmqvist, P. The Epivillafranchian and the arrival of pigs into Europe. Quat. Int. 2015, 389, 131-138. [CrossRef]

89. Steensma, K.J. Plio-/Pleistozäne Großsäugetiere (Mammalia) aus dem Beckem von Kastoria/Grevena, südlich von Neapolis NW-Griechenland. Ph.D. Thesis, Technische Universität Clausthal, Clausthal, Germany, 1988.

90. Palombo, M.R. To what extent could functional diversity be a useful tool in inferring ecosystem responses to past climate changes? Quat. Int. 2016, 413, 15-31. [CrossRef] 